\title{
A review of sulfoxaflor, a derivative of biological acting substances as a class of insecticides with a broad range of action against many insect pests
}

\author{
L. Bacci, ${ }^{1}$ S. Convertini, ${ }^{2}$ B. Rossaro ${ }^{3}$ \\ ${ }^{1}$ Dow Agrosciences Italia, Bologna; ${ }^{2}$ ReAgri srl, Massafra (TA); ${ }^{3}$ Department of Food, Environmental and Nutritional \\ Sciences, University of Milan, Italy
}

\begin{abstract}
Sulfoxaflor is an insecticide used against sap-feeding insects (Aphididae, Aleyrodidae) belonging to the family of sulfoximine; sulfoximine is a chiral nitrogen-containing sulphur (VI) molecule; it is a sub-group of insecticides that act as nicotinic acetylcholine receptor (nAChR) competitive modulators. Sulfoxaflor binds to $\mathrm{nAChR}$ in place of acetylcholine and acts as an allosteric activator of nAChR. Thanks to its mode of action resistance phenomena are uncommon, even few cases of resistance were reported. It binds to receptors determining uncontrolled nerve impulses followed by muscle tremors to which paralysis and death follows. Sulfoxaflor acts on the same receptors of neonicotinoids as nicotine and butenolides, but it binds differently. It binds to insects nAChRs more strongly than to mammals' ones, so it is much less toxic for mammals and man. Sulfoxaflor is supposed to have a low environmental impact and is not much aggressive against non-target species. Unfortunately, it is toxic to impollinator insects, so it must be used only in compliance with a series of legislative norms. At present sulfoxaflor can be considered one of the most interesting products to be used in fighting against agriculture insect pests.
\end{abstract}

Correspondence: Bruno Rossaro, Department of Food, Environmental and Nutritional Sciences, University of Milan, via Celoria 2, 20133 Milan, Italy.

E-mail: bruno.rossaro@unimi.it

Key words: sulfoxaflor, insecticides, target species, resistance

Contributions: the authors contributed equally.

Conflict of interest: the authors declare no potential conflict of interest.

Funding: Research supported by Dow Agrosciences Italia S.r.l.

Received for publication: 18 September 2018.

Accepted for publication: 18 September 2018.

CCopyright L. Bacci et al., 2018

Licensee PAGEPress, Italy

Journal of Entomological and Acarological Research 2018; 50:7836

doi:10.4081/jear.2018.7836

This article is distributed under the terms of the Creative Commons Attribution Noncommercial License (by-nc 4.0) which permits any noncommercial use, distribution, and reproduction in any medium, provided the original author(s) and source are credited.

\section{Introduction}

Insecticides are important tools in the control of insect pests. An unexpected unfavourable consequence of the increased use of insecticides was the reduction of pollinator species and the subsequent declines in crop yields. Multiple factors in various combinations as modified crops, habitat fragmentation, introduced diseases and parasites, including mites, fungi, virus, reduction in forage, poor nutrition, and queen failure were other probable contributory causes of elevated colony loss of pollinator species, but the reduction of pollinator species was often attributed to some classes of insecticides.

In an effort to reduce the unfavourable consequences of an indiscriminate use of insecticides, their usage is actually regulated by a detailed complex of norms to avoid an unreasonable environmental risk. In any case the economic, social, and environmental costs and benefits connected with their use should be taken into account. For this reason, beyond the research efforts in discovering new formulas and new mechanisms of actions, there is the actual tendency to introduce mitigation measures following a series of legislative norms. Insecticide Resistance Management (IRM) programs have the aim to promote research to manufacture products that exhibit high potency and lack insecticidal crossresistance (Babcock et al., 2011). The aim is to reduce the adverse effects of their unregulated use, avoiding the insurgence of resistance phenomena, considering that a total banning of insecticides is at present impossible and unrealistic and the present situation is not expected to change in the immediate or less immediate future.

Neonicotinoids (neonics) act as plant systemic, especially suited in control of sucking insects, they are effective also in flea control on dogs and cats. They are a new generation of insecticides that has its historical basis on the use of tobacco nicotine to control pest plants since fifteen centuries. Seven groups of neonics are actually known (Figure 1, Table 1): Butenolide, Cyanoimines (NCN), Mesoionic, nitroimines $\left(\mathrm{NNO}_{2}\right)$, nitromethylene $\left(\mathrm{CHNO}_{2}\right)$, Nicotinoids and Sulfoximine. Imidacloprid, clothianidin, thiamethoxam, and dinotefuran are the most known compounds among nitroimines group, cycloxaprid, nitenpyram among nitromethylene compounds, acetamiprid and thiacloprid among the cyanoimines, the old nicotine among nicotinoids and sulfoxaflor among sulfoximine.

Neonicotinoids were developed to control species detrimental to agriculture, but they were also used to control insects of sanitary interest. They were tested on many pest species, the most investigated are summarized in Table 2, together some predators and parasitoids.

The efficacy of an insecticide was traditionally measured as $\mathrm{LC}_{50}$ or $\mathrm{LD}_{50}$ that is the concentration or the amount of a substance 
respectively determining $50 \%$ mortality of insect pest. At present the toxic action of neonicotinoids is supposed to be related to their capacity to bind to the $\mathrm{nAChR}$ receptors. So, beyond $\mathrm{LC}_{50}$ measure, their toxicity can be measured with electrophysiological tests, as $\mathrm{IC}_{50}$, where $\mathrm{IC}_{50}$ is the ligand Insecticide Concentration that reduces the acetylcholine (Ach) induced current by $50 \%$. The technique used to measure the induced Ach current is based on the patch clamp technique that studies ionic currents in individual isolated cells or patches of cell membrane. The technique is especially useful in the study of excitable cells such as neurons to study ion channels performance. Borosilicate glass electrodes filled with a solution of known osmolarity are connected to a patch-clamp amplifier and acetylcholine (Ach) induced currents measured (Oliveira et al., 2011).

The research around neoticotinoids (shortened to "neonics"), in an attempt to discover products able to bypass the insecticideresistance phenomena, put on the market new products. Among them the novel sulfoximine insecticide sulfoxaflor (isoclast active $^{\mathrm{TM}}$, Closer $^{\circledR}$ ) was proposed as a potent and more effective insecticide than the neonicotinoids thanks to toxicity to many insect pests as green peach aphids (GPA, M. persicae, Table 2).

All neonics are nicotinic acetylcholine receptor (nAChR) agonists with a similar mode of action and target-site cross-resistance, despite some important differences in their formula, and are much more effective on insect than on mammalian nAChRs at defined binding sites (Tomizawa \& Casida, 2003).

The neonics, in comparison with the old nicotine, have the advantage to be readily metabolized and have favourable toxicological profiles, unfortunately they are very toxic to impollinators (Casida, 2018; Siviter et al., 2018). Honey bees are highly sensitive to nicotinoids indeed, even if some toxicity differences between the different groups are apparent, the nitroimines and nitromethylenes appearing as the most toxic and with high photolability, while the cyanoimines should be the less toxic to bees according to experimental evidences (Table 3) (Iwasa et al., 2004).

The sulfoximines, as exemplified by sulfoxaflor ([NImethyloxido[1-[6-(trifluoromethyl)-3-pyridinyl]ethyl]-lamb$\mathrm{da}(4)$-sulfanylidene]cyanamide] represent a new class of insecticides. Sulfoxaflor is a chiral (that is a compound that can be distinguished by its mirror image) nitrogen-containing sulphur (VI) molecule, it exhibits a high degree of efficacy against a wide range of sap-feeding insects, including those resistant to neonicotinoids and other insecticides. Sulfoxaflor is an agonist at insect nicotinic acetylcholine receptors (nAChR) and seems to function in a manner distinct from other insecticides acting at nAChRs, because the sulfoximines exhibit Structure Activity Relationships (SAR) that are different from other nAChR neonicotinoids agonists. The sulfoximine SAR mode of action and the biochemistry underlying the observed efficacy on resistant insect pests, with a particular focus on sulfoxaflor reserves attention. Butenolide flupyradifurone is structurally related and shows a similar action.

Sulfoxaflor, as a new alternative sucking pest insecticide used in Integrated Pest Management (IPM) programs; was developed by Dow AgroSciences and it is supposed to have a new mode of action so sulfoxaflor is not considered a neonicotinoid, even if there is no agreement in this point, because some authors suggest that sulfoxaflor should be considered a neonicotinoid because a point mutation in $M$. persicae determines a cross-resistance to all exprimented neonicotinoids including sulfoxaflor (Cutler et al., 2013).

Insecticide Resistant Action Committee (IRAC) has classified its unique mode of action in the new subgroup $4 \mathrm{C}$ of Sulfoximines. Sulfoxaflor is extremely effective against many sap-feeding insects, including scales, aphids, leafhoppers and whiteflies
(Bedford et al., 1994) in all major crops, such as pome fruits, stone fruits, citrus, vegetables and ornamentals.

The registration of $\mathrm{Closer}^{\circledR}, 120 \mathrm{SC}$ formulation of sulfoxaflor on solanaceae, cucurbits and lettuce in the open field and greenhouse, as well as on legumes, brassicas, potato, ornamentals, pome, stone, citrus fruit has been requested. Label extensions are planned for vine, strawberry and artichoke. (Tescari et al., 2016)

For its new mode of action and its favourable toxicological and eco-toxicological profile, sulfoxaflor is an ideal tool for IPM programs; the contact and anti-feeding activity ensure a high knockdown effect against adults of whiteflies and a prolonged efficacy on neanids.

The aim of the present review is to summarize the most recent progress in clarifying the mechanism of action, toxicity and efficacy of the sulfoxaflor and to present some experimental evidence of their effects.

\section{Toxicity on target organisms}

In 2010, Dow AgroSciences LLC applied to the US Environmental Protection Agency (EPA) for the registration of sulfoxaflor, as a new systemic insecticide (EPA (US Environmental Protection Agency), 2010). This insecticide was thereafter available for use in the European Union (EC, 2015, 2017) (Centner et al., 2018).

Sulfoxaflor exhibits high potency and lacks insecticidal crossresistance, so it is particularly useful in insecticide resistance management (IRM) programs; it is the first compound under development from the novel sulfoxamine class of insecticides. In the laboratory, sulfoxaflor demonstrated high levels of insecticidal activity against many sap-feeding insects species. The efficacy of sulfoxaflor was comparable with that of other neonicotinoids, for the control of a wide range of aphids, whiteflies (Sternorrhyncha) and true bugs (Heteroptera).

In the following table (Table 2) the species that are target of sulfoxaflor, their parasitoids and predators are given together some impollinator species; some congeneric species present in Italy are also reported.

Sulfoxaflor was successfully used against the following species (Table 2): A. aurantii, $P$. citri on citrus, $P$. comstocki and $P$. pentagona on Drupaceae, P. ficus, T. vitis and P. corni on vine (Convertini et al., 2018a), D. plantaginea on apple (Boselli et al., 2018), A. gossypii on horticultural crops (Convertini et al., 2018b), $V$. vitifoliae on vine (Bacci et al., 2018a).

Sulfoxaflor performed well in the laboratory against both insecticide-susceptible and insecticide-resistant populations of sweetpotato whitefly, B. tabaci, (Table 2) and brown plant-hopper, $N$. lugens (Table 2), including populations resistant to the neonicotinoid imidacloprid. These trends were confirmed in the field from different area and for different crops, and in populations of insects with repeated exposure to insecticides. In particular, a sulfoxaflor use rate of $25 \mathrm{~g} \mathrm{ha}^{-1}$ against cotton aphid (A. gossypii, Table 2) outperformed acetamiprid $\left(25 \mathrm{~g} \mathrm{ha}^{-1}\right)$ and dicrotophos (560 $\left.\mathrm{g} \mathrm{ha}^{-1}\right)$. Sulfoxaflor $\left(50 \mathrm{~g} \mathrm{ha}^{-1}\right)$ provided also a control of sweetpotato whitefly similar to acetamiprid $\left(75 \mathrm{~g} \mathrm{ha}^{-1}\right)$ and imidacloprid $\left(50 \mathrm{~g} \mathrm{ha}^{-1}\right)$ and performed better than thiamethoxam $(50 \mathrm{~g}$ $\mathrm{ha}^{-1}$ ). The novel chemistry of sulfoxaflor, its unique biological spectrum of activity and lack of cross-resistance highlight the potential of sulfoxaflor as an important new tool for the control of sap-feeding insect pests (Babcock et al., 2011).

B. tabaci and T. vaporariorum (Table 2) are two of the most polyphagus, problematic and persistent greenhouse pests. They are 
phloem sap feeding pests, but indirect damages are often more serious than direct damages; indirect effects are caused by sooty mold fungus and by virus transmission, especially Geminivirus (De Barro et al., 2011). Pest insects determine damage to Cucurbitaceae, Leguminosae, Euphorbiaceae, Malvaceae and Solanaceae (Bedford et al., 1994)). These two-whitefly species are often a considerable problem under glass, especially in more temperate areas.

T. vaporariorum is a very polyphagous pest, more dangerous in protected crops and transmits a limited number of viruses, all within the genera Crinivirus and Torradovirus (Wisler et al., 1998; Brown, 2007; Navas-Castillo et al., 2011).

B. tabaci is a serious pest of both open-air and protected cropping (e.g. Spain, Israel and Europe-Mediterranean area). It includes a complex mix or genetically but not morphologically distinguishable populations, which have been referred as biotypes. Recently, it has been proposed that B. tabaci is a complex of different species (Dinsdale et al., 2010; De Barro et al., 2011, see also Table 2).

Middle East-Asia minor 1 (MEAM1, formerly biotype B) (Demichelis et al., 2000) and Mediterranean (MED, formerly biotype Q) are the most common and polyphagous species of the $B$. tabaci complex found in Italy (Demichelis et al., 2000; Bosco et al., 2001) and worldwide; they are both responsible for the transmission and appearance of Begomoviruses and some Criniviruses worldwide.

These two biotypes (B and $\mathrm{Q}$ ) differ in a range of biological characteristics, including host plant range and adaptability, ability to transmit plant virus, copulation efficiency, composition of harboured symbionts, and expression of resistance to heat shock and insecticides (Iida et al., 2009; Ahmad et al., 2009; Horowitz et al., 2005; Elbaz et al., 2011; Liu et al., 2012; Fang et al., 2013). These differences contribute to the competitive outcomes between the two biotypes in various habitats. The biotype $\mathrm{B}$ is more adapted to open fields, whereas the biotype $\mathrm{Q}$ is more competitive in protected agricultural facilities (Kontsedalov et al., 2012; Hsieh et al., 2012). Whiteflies, especially Bemisia complex, have been reported to develop resistance to a wide range of insecticides, including conventional ones such as organo-phosphates, carbamates, pyrethroids, and novel ones, such as neonicotinoids and insect growth regulators (Kontsedalov et al., 2012; Luo et al., 2010; Wang et al., 2010; Ahmad et al., 2010). Their control depends heavily on insecticides because of their easy application, quick action, and high efficacy. The prolonged presence in the greenhouse of both crop and pests at high temperature causes a large number of whiteflies generations and a consequent high number of treatments. However, repeated spray applications with the same insecticide induce various issues e.g. impact on non-target organisms (Guedes et al., 2016; Desneux et al., 2007) and the selection of resistant pest populations (Roditakis et al., 2015; Campos et al., 2015; Liang et al., 2012). For these reasons it becomes necessary the rotation of different active ingredients with different mode of action (Integrated Pest Management, or IPM strategy).

Greenhouse studies were carried out using a randomized complete block design in evaluating the action of six insecticides on transmission of virus. The virus was Tomato yellow leaf curl virus (TYLCV) transmitted by B. tabaci biotype B Gennadius to tomato, Lycopersicon esculentum (Miller) (Solanales: Solanaceae). The tomato seedlings were inoculated with whiteflies from a TYLCV colony in cages 3,7 , or $14 \mathrm{~d}$ after treatment with insecticide. The research had the aim to reveal differences in residual efficacy of six insecticides. Four insecticides were near registration for use on tomato: they were cyazypyr, flupyradifurone, pyrafluquinazon, and sulfoxaflor and two were just authorised: pymetrozine and a zeta-cypermethrin/bifenthrin combination. Differences in efficacy were expected because these six materials represent distinct modes of action and both contact and systemic materials. Percentage of tomato seedlings expressing virus symptoms tended to be lowest in seedlings treated with flupyradifurone. The zetacypermethrin/bifenthrin insecticide demonstrated comparable efficacy to flupyradifurone in some trials at 3 and $7 \mathrm{~d}$ after treatment inoculations, but not the $14 \mathrm{~d}$ after treatment inoculation. Pyrafluquinazon was not statistically different from cyazypyr or sulfoxaflor in percentage of plants with virus symptoms in any trial. Percentage virus in the cyazypyr and sulfoxaflor treatments was not statistically different in the 3 and 7 days after treatment inoculations. Among seedlings treated with insecticide, percentage with virus symptoms tended to be highest in the seedlings treated with pymetrozine; in conclusion sulfoxaflor had an efficacy similar to the other five insecticides used (Smith \& Giurcanu, 2014).

The Asian citrus psyllid, D. citri is the most important international pest of citrus because it transmits the bacteria that cause huanglongbing (HLB). HLB limits citrus production globally. The toxicity of sulfoxalor against $D$. citri was evaluated. Sulfoxaflor was as toxic as imidacloprid to adult $D$. citri. The $\mathrm{LC}_{50}$ values for

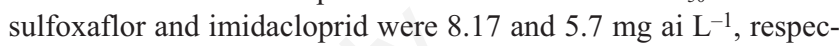
tively. Treatment with sulfoxaflor resulted in reduced oviposition, development of nymphs, and emergence of adult $D$. citri on plants, as compared with controls. The lowest concentration that reduced adult emergence was $0.6 \mathrm{mg}$ ai $\mathrm{L}^{-1}$. There was reduced feeding by $D$. citri adults on leaves treated with sulfoxaflor. The residual toxicity of sulfoxaflor was equivalent to imidacloprid. Under field conditions, formulated sulfoxaflor reduced populations of $D$. citri compared with untreated controls. Sulfoxaflor is a novel mode of action and is an effective tool for $D$. citri management; in this context its action seems similar to the one of imidacloprid (Brar et al 2017). Vial assay (Dow AgroSciences , 2017) carried out on $M$. persicae gave an $\mathrm{LC}_{50}$ of $0.11 \mu \mathrm{g} / \mathrm{vial}$ for sulfoxaflor, $0.23 \mu \mathrm{g} / \mathrm{vial}$ for imidacloprid and $0.81 \mu \mathrm{g} /$ vial for acetamiprid, indicating that sulfoxaflor is $\sim 2 \times$ more active than imidacloprid and $\sim 7 \times$ more active than acetamiprid. In comparison with spirotetramat and flonicamid it reduces the production of honeydew in $M$. persicae (Dow AgroSciences, 2017).

The results of toxicity tests on different target species are summarized in Tables 4-7. In these Tables the $\mathrm{LC}_{50}\left(\mathrm{LC}_{95}\right)$ and their fiducial limits of different neonicotinoids on different target species are given.

\section{Toxicity on insect predators or parasitoids of useful species}

Integrated Pest Management (IPM) strategies against crop pests must consider the side effects of insecticides on species that act as biological control agents. The toxicity and sublethal effects (fecundity and fertility) of the following neonicotinoids flonicamid, flubendiamide, metaflumizone, spirotetramat, sulfoxaflor and deltamethrin were tested on the predators $C$. carnea and $A$. bipunctata (Table 2), natural enemies of insect pests. The side effects of the active ingredients were evaluated utilizing residual contact tests for the larvae and adults of these predators; the test were carried out in laboratory. Flonicamid, flubendiamide, metaflumizone and spirotetramat appeared not toxic to last instar larvae and adults of $C$. carnea and A. bipunctata, whereas sulfoxaflor resulted slightly toxic to adults of $C$ carnea and was highly toxic to the L-4 larvae of A. bipunctata. For A. bipunctata sulfoxaflor and deltamethrin were the most toxic determining a $100 \%$ larval mortality. Deltamethrin was also very toxic to larvae and adults of 
C. carnea. In accordance with the results obtained, the compounds flonicamid, flubendiamide, metaflumizone and spirotetramat should be incorporated into IPM programs in combination with these natural enemies for the control of particular greenhouse pests. The use of sulfoxaflor and deltamethrin in IPM strategies should be considered when either of these biological control agents is released, because of the toxic behaviour observed under laboratory conditions. It is need to develop a sustainable approach combining the use of insecticides in ecosystems in which these natural enemies are present is recommended to obey to the directives of the IPM (Garzon et al., 2015)

\section{Toxicity on beneficial and non-target organisms}

\section{Toxicity to impollinators}

The efficacy of an insecticide on target species is of primary importance to select it among other products, but its effects on beneficial and not target species and on human health must also be taken into account.

In this context the registration of sulfoxaflor in the United States was accompanied by four mitigation measures, that were recommended to reduce the risk of harm to pollinator species (Table 8). Another mitigation measure is avoiding its use when air humidity is high (Bottacini, 2012).

The need to take additional steps and to adopt a greater variety of measures was in any case recommended, given the importance of pollination to food crops. It is necessary to take adequate measures to mitigate harm to pollinators; this aim could be reached through a comparison of different regulatory options for use of insecticides.

Rather than advocating that harmful insecticides be banned, as the European Union has done on a temporary basis for neonicotinoids [EC (European Commission), 2013], it is proposed to facilitate agricultural production with accompanying mitigation measures to reduce adverse effects on pollinator species. The measures would need to prevent unacceptable levels of pollinator declines in areas where they are used.

Honey bee populations began to drastically decline in 2006 in USA determining the so-called Colony Collapse Disorder. Pesticides belonging to the class of neonicotinoids quickly emerged as identifiable responsibles with an $\mathrm{LC}_{50}$ of $0.81 \mathrm{ng}$ a.i. diet $\mu \mathrm{L}^{-1}$ (or $0.81 \mu \mathrm{g}$ a.i. diet $\mathrm{mL}^{-1}$, or $0.81 \mathrm{mg}$ a.i. diet $\mathrm{L}^{-1}$ or 0.81 ppm a.i. diet) (Tables 9-12). In response the Environmental Protection Agency (EPA) developed an ecological risk assessment framework at different levels to better analyse the risk that pesticides caused to honey bees and other insect pollinators. In 2012, the EPA applied guidelines to the application for registration of a new type of neonicotinoid, sulfoxaflor. Sulfoxaflor registration was approved despite its high risks to honey bees (Table 12), but led also to the creation of the Pollinator Risk Assessment guidelines. These new guidelines included set standards that allowed the use of sulfoxaflor with a reduced risk, but pollinator advocates had an instrument from then on to successfully challenge a registration whenever an environmental risk is threatened (Vanegas, 2017).

Transform (sulfoxaflor) alone had $71 \%$ and $88 \%$ bee mortality, respectively, significantly higher than that of Advise (imidacloprid) alone and the mixtures of Advise with Transform (Zhu et al, 2017).

Different neonicotinoids have different mechanism of action on impollinators. Interestingly, the less toxic neonicotinoids or neonics ("bee safe") have a cyanoimine substituent (THIA and ACET) ("magic cyano" for safety), while the more toxic ones ("bee tox") have a nitroimine or nitromethylene substituent ("magic nitro" for toxicity) (Tables 1 and 3).

Cytochrome P450 (CYP6G1) monooxygenases play a major role in neonic resistance and they are probably involved in toxicity mechanism to bees. These monooxygenases are very effective in degrading many insecticides, and the ability of sulfoxaflor to escape the degradation by Cytochrome P450 monooxygenase CYP6G1 (Sparks et al., 2012) makes sulfoxaflor very effective against insect pests avoiding the mechanism of resistance, but also harmful to non-target species as bees.

Differences between cyanoimines and nitroimines toxicity are not due to the sensitivity of the bee to $\mathrm{nAChR}$ binding sites or formation of bioactivated metabolites, but instead to an efficient CYP450 oxidative detoxification mechanism for the cyanoimine compounds; in this respect sulfoxaflor is more similar to nitroimines than to cyanoimines (Watson et al., 2011).

\section{Toxicity to other beneficial arthropods}

Sulfoxaflor has low impact on other benefical arthropods (Dow AgroSciences, 2017), as:

Coleoptera: Coccinellidae, Nitidulidae, Staphylinidae

Neuroptera: Chrysopidae

Hemiptera: Anthocoridae, Miridae

Hymenoptera: Aphelinidae, Encyrtidae, Braconidae

Predatory mites (Phytoseiidae) and spiders

Results of test of toxicity on beneficial arthropods are summarized in Table 13.

\section{Toxicity to parasitoids}

Little information is available about the effects of sulfoxaflor on parasitoids. Only the toxicity of sulfoxaflor against $T$. radiata a parasitoid of $D$. citri was evaluated. Sulfoxaflor was almost as toxic as imidacloprid for adults of D.citri with an $\mathrm{LC}_{50}$ of $8.17 \mu \mathrm{g}$ ai $\mathrm{mL}^{-1}$.for sulfoxaflor and $5.7 \mu \mathrm{g}$ ai $\mathrm{mL}^{-1}$ for imidacloprid. The $\mathrm{LC}_{50}$ of sulfoxaflor for adults of $T$. radiata was 3.3 times greater than for $D$. citri adults, this result allows to state that sulfoxaflor is less toxic to parasitoid than to target species (Brar et al., 2017).

\section{Toxicity to plants}

Stress tolerance in plants is induced by some neonicotinoids via salicylate-associated systems, but this mechanism of action is not demonstrated for sulfoxaflor (Casida, 2018), so at present there is no evidence for a direct effect of sulfoxaflor on plants.

Sulfoxaflor shows a translaminar activity and is able to protect plant canopy and undersides leaves. The acute toxicity to the aquatic plant Lemna gibba (duckweed) is very low with a 7 days EC50 >99 $\mathrm{mgL}^{-1}$ (Dow AgroSciences, 2017)

\section{Toxicity to mammals}

Registration of new plant protection products (e.g., herbicide, insecticide, or fungicide) requires comprehensive mammalian toxicity evaluation including carcinogenicity studies in rodents, rats, mice and man. Carcinogenicity tests results influence the process of authorization of insecticide in agriculture also. Regulatory agencies expectation, in order to understand the relevance of a specific tumor finding to human health, is that a systematic, transparent, and hypothesis-driven mode of action (MoA) investigation be carried out. A novel approach of generating MoA data was implementing additional end points to the standard guideline toxicity studies with sulfoxaflor. This MoA approach resulted in a more robust integration of molecular with apical end points while minimizing animal use. Sulfoxaflor induced liver effects (increased liver weight due to hepatocellular hypertrophy) in an initial palatability probe study for 
selecting doses for subsequent repeat-dose dietary studies and induced liver tumors in rats and mice in the bioassays. The MoA data available by the time of the carcinogenicity finding supported the conclusion that the carcinogenic potential of sulfoxaflor was due to two nuclear receptors (NR) activation (CAR and PXR) with subsequent hepatocellular proliferation. NR mechanism is explained in the section "Action at cellular level" (see below). This MoA was not considered to be relevant to humans as sulfoxaflor is unlikely to induce hepatocellular proliferation in humans and therefore would not be a human liver carcinogen (LeBaron et al., 2013).

Results of some toxicity tests on mammals are summarized in Table 14 (Dow AgroSciences, 2017)

\section{Action at cellular level}

Sulfoxaflor belongs to sulfoximines and, as other neo-nicotinoids as nitroimines (imidacloprid), butenolides and mesoionic triflumezopyrim (TRIF), block insect nicotinic acetylcholine receptors (nAChR). Sulfoxaflor has a unique Mechanism of Action (MOA) involving the disruption of $\mathrm{nAChR}$. It acts as activator of nAChR (Figures 2 and 3), through a site that is supposed to be distinct from other neo-nicotinoids or nicotinic active sites.

The mesoionic TRIF acts as a nAChR competitive modulator with little or no target-site cross-resistance. Butenolides and mesoionic TRIF act as competitive modulators of imidacloprid binding to $\mathrm{nAChR}$ in the same manner of the radioisotope $\left[{ }^{3} \mathrm{H}\right] \mathrm{imi}-$ dacloprid ( $\left.\left[{ }^{3} \mathrm{H}\right] \mathrm{IMI}\right)$ (tritiated radiolabelled imidacloprid) (Casida, 2018) allowing radioligand binding studies.

The action of sulfoxaflor was characterized using electrophysiological and radioligand binding techniques (Watson et al., 2011) and thanks to these studies it was discovered that it acts at nAChR sites (Figure 4). When tested for agonist properties on Drosophila melanogaster Da2nAChR subunit, sulfoxaflor elicited very high amplitude currents. Sulfoximine analogs of sulfoxaflor were also agonists on $\mathrm{Da} 2 / \mathrm{b} 2 \mathrm{nAChR}$, but did not produce high currents equivalent to sulfoxaflor and were not toxic to green peach aphid (GPA). Only clothianidin, among the neonicotinoids produced maximal currents as large as those produced by sulfoxaflor. It can be concluded that the potent insecticidal activity of sulfoxaflor is probably bound to its very high efficacy at nAChR. In contrast, sulfoxaflor displaced [(3)H]IMI from green peach aphid nAChR membrane preparations with weak affinity compared to most of the neonicotinoids examined. The nature of the interaction of sulfoxaflor with nAChR apparently differs from that of IMI and other neonicotinoids, and when coupled with other known characteristics (novel chemical structure, lack of cross-resistance, and metabolic stability), indicate that sulfoxaflor represents a significant new insecticide option for the control of sap-feeding insects. The maximal currents induced by sulfoxaflor were significantly larger than those induced by imidacloprid (Zhu et al., 2011).

The average number of ligand molecules bound per binding partner [LP] is a function of ligand concentration [L], its binding affinity $\mathrm{K}$ and number of binding sites $\mathrm{N}$ :

$$
[L P]=\frac{N K[L]}{1+K[L]}
$$

The binding affinity $K$ is the association constant defined as:

$$
K=\frac{[L P]}{[L][P]}
$$

where $[\mathrm{LP}]$ and $[\mathrm{L}]$ are as above and $[\mathrm{P}]$ is the ligand protein concentration.
The above equation may be linearized (Scatchard equation) rewriting it as:

$$
[L P]=(N-[L P]) K[L]
$$

dividing both members by [L] we obtain:

$$
\frac{[L P]}{[L]}=N K-K[L P]
$$

allowing to plot a graph with [LP] as abscissa and [LP]/[L] as ordinate, in this manner a straight line is obtained with a slope equal to $-\mathrm{K}$ and an origin intercept equal to NK (Figure 5); the steepest the line, the highest the $\mathrm{K}$; it is evident that a higher number of free sites gives lower ordinate values (Figure 5), meaning lower affinity of the compound for the receptor protein. In other words, if a compound has a low affinity for a binding site it is less able to compete with $\left[{ }^{3} \mathrm{H}\right] \mathrm{IMI}$ in occupying the binding sites; and a steeper line is observed (K larger), meaning that in correspondence of the same number of sites bound (same abscissa values [LP]) a higher number of free sites $[\mathrm{L}]$ is observed (lower ordinate value $[\mathrm{LP}] /[\mathrm{L}]$ ) (Figure 5).

Sulfoxaflor shows higher association constant, (that in the present case has the meaning of an Inhibition Constant) $(\mathrm{K}=265 \pm 49)$ respect to imidacloprid $(\mathrm{K}=5.1 \pm 0.7)$ meaning lower affinity for $\left[{ }^{3} \mathrm{H}\right] \mathrm{IMI}$ binding site (Watson et al., 2011). This evidence is used to support the hypothesis that sulfoxaflor is not a true neonicotinoid.

Some structural differences in $\mathrm{nAChR}$ binding sites explaining the different sensitivity of different species to acetylcholine, nicotine and different groups of neonicotinoids including sulfoxaflor are not well known. A substantial difference is only known between mammalians and insects, and is bound to the presence of an anionic subsite in mammalian nAChR and a cationic subsite in insects nAChR (Tomizawa \& Casida, 2003). Different binding sites present in nAChRs of insects are supposed to bind acetylcholine, neonicotinoids and sulfoxaflor differently (Figure 4), but at present only indirect evidence based on different signals and different toxicity of the various molecules is available.

The mechanism of synthesis suppression of the so-called Nuclear Receptors (NR) through small or short interfering RNA (siRNA) is here summarized to clarify the experiment exposed in the following section. When long double-stranded RNA (dsRNA) molecules are given to a cell, an enzyme cleaves dsRNA into short double-stranded fragments called siRNA. Each siRNA is thereafter unwound into two single-stranded RNAs (ssRNAs), the passenger strand and the guide strand. The passenger strand is degraded and the guide strand is incorporated into the RNA-induced silencing complex (RISC). In RISC the guide strand pairs with a complementary sequence of a messenger mRNA molecule and induces the cleavage of this mRNA determining its consequent silencing (Figure 6). In this manner the mRNA implied in the production of NR is silenced and NR production is suppressed.

Different responses caused by different insecticides, including insecticide mechanism of resistance, can be explained by the ability of different molecules to silence the NR. It is known that nuclear receptors activating metabolism of xenobiotic compounds occurs in insects. These NR are implied in detoxification mechanism and their production is stimulated in insects resistant to insecticides and is probably at the basis insecticide resistance. Sulfoxaflor induces the expression of a family of NR in an attempt of the insect to degrade the insecticide. Sulfoxoflor induces expression of different NR with a different time table and some are expressed after $24 \mathrm{~h}$ others after $48 \mathrm{~h}$. Different organs can accumulate different concentrations of NR.

The employment of gene silencing RNAi (interference RNA) confirmed the mechanism of action of sulfoxaflor. The synthesis 
suppression of NR determined by RNAi caused the death of N.lugens, confirming that sulfoxaflor acts promoting synthesis of NR. dsRNA (double filament RNA) feeding, significantly silenced NR receptors compared with the control. The notable and specific knockdown of above NR genes resulted in a higher nymph mortality, suggesting that the RNAi-mediated silencing of above NR genes increased the susceptibility of $N$. lugens to sulfoxaflor (Xu et al, 2017).

\section{Resistance and cross-resistance}

The emergence of resistant insects is a common situation when an insecticide is spread for long time (Roush \& Tabashnik, 1991; Lawrence \& Sarjeet, 2010), thus the potential development of a resistance in an insect should be evaluated.

A problem connected with resistance is also the cross-resistance, which is observed when the same mechanism of resistance allows the insect to resist to different insecticides.

Compounds that are effective against pests such as the whiteflies B. tabaci and T. vaporariorum, which show resistance to a range of insecticidal modes of action (MOA), have particular value as components of resistance management programmes. The sulfoximine insecticides are chemically unique as they are the first compound in this category of insecticides that incorporate a sulfoximine functional group. Sulfoxaflor is the first sulfoximine compound under commercial development for the control of sap-feeding insects. Its crossresistance relationships were investigated by comparing the responses of field-collected strains with those of insecticide-susceptible laboratory strains of $B$. tabaci and T. vaporariorum.

Resistance ratios (RR) are calculated to monitor the evolution of insecticide resistance in a field population. $R R$ is calculated dividing the $\mathrm{LC}_{50}$ of the field population by the $\mathrm{LC}_{50}$ of a susceptible strain. When RR is ${ }^{3} 10$ the target field population is considered highly resistant.

Sulfoxaflor tested against strains of $B$. tabaci exhibited an RR of about 3, while imidacloprid tested against the same strains of $B$. tabaci produced an RR of up to 1000-fold RR. Imidacloprid emphasized cross-resistance to other neonicotinoid insecticides, while sulfoxaflor was not cross-resistant; similarly a strain of $B$. tabaci exhibiting resistance to a pyrethroid (deltamethrin) and to an organophosphate (profenophos) did not exhibit cross-resistance to sulfoxaflor. No cross-resistance was also observed between sulfoxaflor and imidacloprid in T. vaporariorum. Three field strains of $T$. vaporariorum showed only slightly reduced susceptibility to sufloxaflor with an RR of 4.17 expressed by only one strain of three. On the contrary, the same population of $T$. vaporariorum exhibited an RR of more than 23.8-fold for imidacloprid relative to the susceptible population. Sulfoxaflor shares a target site with neonicotinoids (the nicotinic acetylcholine receptor), but it is largely unaffected by existing cases of neonicotinoid resistance in $B$. tabaci and $T$. vaporariorum. Neonicotinoid resistance mechanisms in $B$. tabaci and T. vaporariorum are known to be primarily based on enhanced detoxification of insecticide. This detoxification mechanism is inactive with sulfoxaflor, determining lack of cross-resistance of this insecticide, so here again it can be stated that sulfoxaflor is a valuable tool for the management of sap-feeding insect pests, which are resistant to other neonicotinoids (Longhurst et al., 2013).

A resistance mechanism to insecticides is differently expressed in response to different products by different strains of insect pests. The cotton aphid $A$. gossypii (ThR) developed a strain displaying a thiamethoxam-resistance 13.79 -fold greater than a susceptible cotton aphid (SS) strain. The toxicity of thiamethoxam in the resistant strain was synergistically increased by Piperonyl butoxide (PBO) and triphenyl phosphate (TPP), whereas significant synergistic effects were not exhibited by diethyl maleate (DEM). The ThR strain developed increased levels of cross-resistance to bifenthrin (11.71 fold), cyfluthrin (17.90 fold), esfenvalerate (6.85 fold), clothianidin (6.56 fold), methidathion (5.34 fold) and a-cypermethrin (4.53 fold), whereas cross-resistance to malathion, omethoate, acephate, chlorpyrifos, methomyl, sulfoxaflor or imidacloprid was not expressed. Bifenthrin toxicity in the resistant strain increased in presence of PBO and TPP by 2.38 and 4.55 fold, respectively. The mRNA expression levels of the a1, a4-1, a4-2, a5 and a7 subunits of nAChR receptors decreased significantly by $332,1.60,2.05,5.41$ and 1.48 fold, respectively, in the resistant strain compared with those in the susceptible strain, as demonstrated by quantitative real-time PCR, but the expression levels of the a2, a3 and b1 subunits were not significantly modified. The ThR strain did not express any target-site mutation within the a1, a2 and b1 subunit of nAChR. Some other mechanism, not attributable to structural modifications of subunits receptors in absence of targetsite mutations, should explain the resistance mechanism. The overexpression of detoxification-related mechanisms including both monooxygenase (cytochrome P450) and esterase could alternatively explain and regulate the levels of thiamethoxam resistance and cross-resistance observed in the ThR strain. The understanding of thiamethoxam resistance mechanism could aid in the management of insecticide-resistant cotton aphids (Wei et al 2017).

A major pest of citrus crops worldwide is the Asian citrus psyllid, D. citri. To manage $D$. citri a large number of insecticides were tested. These practices determined the insurgence of insecticide resistance phenomena. An early warning system is suggested to monitor insecticide susceptibility in populations of $D$. citri, allowing citrus producers to modify chemical control strategies with the aim to reduce the use of chemicals in controlling this pest. Is here described a simple and fast tool to determine insecticide resistance in $D$. citri and apply it to commercial citrus production. $\mathrm{LC}_{50}$ and $\mathrm{LC}_{95}$ estimates were determined for 8 commonly used insecticides on a susceptible laboratory population of D. citri $24 \mathrm{~h}$ after treatment in a residual contact bottle assay. A test was carried out using 5 to 7 concentrations of each insecticide. The $\mathrm{LC}_{50}$ values (and $95 \%$ fiducial limits) ranged from $0.06(0.02-0.26)$ to $0.80(0.26-2.46) \mathrm{ng}$ $\mu \mathrm{L}^{-1}$ for each insecticide tested. Exposure time-mortality indices

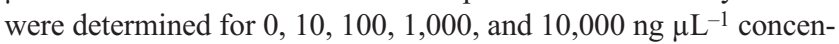
trations of each insecticide in a laboratory susceptible strain. Knockdown was observed after 15, 30, 45, 60, 75, 90, 105, and 120 min. A 100\% knockdown occurred within 60 min using dimethoate, fenpropathrin, imidacloprid, bifenthrin, and flupyradifurone at the $10,000 \mathrm{ng} \mu \mathrm{L}^{-1}$ concentration. Spinetoram determined $86.7 \%$ knockdown within $120 \mathrm{~min}$ at $10,000 \mathrm{ng} \mu \mathrm{L}^{-1}$. Sulfoxaflor and cyantraniliprole were responsible of 44.0 and $42.6 \%$ knockdown, respectively within $120 \mathrm{~min}$ at $1,000 \mathrm{ng} \mu \mathrm{L}^{-1}$. A bottle bioassay was proposed to survey field populations of $D$. citri for insecticide resistance. Exposure time-mortality indices developed in the laboratory were used to assess susceptibility of 1 laboratory and 4 field populations of $D$. citri after $15,30,50,75,90,105$, and $120 \mathrm{~min}$ of exposure at the $10,000 \mathrm{ng} \mu \mathrm{L}^{-1}$ concentration of various insecticides. Bifenthrin, dimethoate, imidacloprid, and fenpropathrin did not emphasize any evidence of resistance. A bottle bioassay appeared suitable for assaying insecticide resistance in D. citri adults under laboratory and field conditions. The bottle bioassay is suggested as a flexible tool for rapid tests of insecticide resistance in possible cases of insecticide failure. It is simple to carry out, allowing trained professionals to a quick monitoring for insecticide resistance of D. citri populations (Chen \& Stelinski, 2017). 


\section{Experimental work}

Trials with sulfoxaflor (isoclast active ${ }^{\mathrm{TM}}$, Closer $^{\circledR}$ ) were carried out in Italy (Center, South and Sicily) in the last three years under greenhouse condition on tomato crops, to have the opportunity to evaluate different control strategies by alternating sulfoxaflor with various standard reference products against $B$. tabaci and $T$. vaporariorum. Samples from the greenhouses were slide mounted to identify the target species (Bacci et al., 2018b).

The studies reported (Tables 15 and 16) were designed as randomized complete block design with four replications and were conducted in compliance with the principles of Good Experimental Practice (GEP) as defined by $91 / 414 /$ EEC Directive and according to the EPPO guidelines PP 1/135(3), 1/152(4), 1/181(4), 1/225(2), 1/239(2), 1/36(3).

Each product was applied in all trials using a backpack engine pump precision sprayer, calibrated to apply different spray volumes per hectare according to the protocols. This equipment mounted hollow cone nozzles Albuz ATR80 Yellow (a) $300 \mathrm{kPa}$.

Adults were assessed in the greenhouse on 20 leaves/plot, while eggs, neanids and pupae were assessed in laboratory on 1 $\mathrm{cm}^{2}$ of leaf surface. All the trials started when the infestation was very low, about 1-2 neanids/leaf. The treatment effect was reported in terms of percentage of efficacy respect to the untreated control by using Abbott formula:

$$
p_{\text {corr }}=\frac{p_{\text {exp }}-p_{\text {cont }}}{1-p_{\text {cont }}}
$$

where $p_{\text {corr }}$ is the mean experimental treatment response corrected for control response, $p_{\exp }$ is the experimental treatment response and $\mathrm{p}_{\text {cont }}$ is the mean control response

Statistical computations were performed by using ARM 2017 software (Gylling Data Management). The data were also processed all together using meta-analysis, obtaining a percentage of overall average effectiveness. Sulfoxaflor and other products were applied at different rates.

\section{Experimental results}

The control of whiteflies in protected crops with a single active substance is always difficult and many times failed the long-lasting protection of the crop. The level of infestation, the timing of application (growth stage of pest) and the capability of the pest to develop resistance are critical to deliver a good control.

Sulfoxaflor gave an excellent knockdown effect on adult stage (Figure 7) combined with high efficacy against neanids after 7 days from application (Figure 8) of both B. tabaci and T.vaporariorum. Knockdown effect in insects following application of an insecticide may be defined as the state of intoxication and partial paralysis which usually precedes death.

Exploiting the combined action on the two whitefly stages and considering that at the beginning of the infestation there are mainly adults and neanids, it is useful to optimize the positioning of sulfoxaflor, often at the beginning of spray program exploiting the knockdown effect on the adult stage and the consequent reduction of the oviposition activity.

To evaluate the control strategies, it was combined with products with different mode of action, in particular flonicamid (strate- gy with a low impact on useful organism) and spirotetramat (exploiting persistence and control on neanids) (Table 17).

Flipper (Potassium salts of fatty acids $47.8 \mathrm{~g}$ [479.8 g/L], was applied at the end of all the strategies, it maintained a good control of the populations, suggesting its use near the harvest thanks to its favourable toxicological and ecotoxicological profile and the different mode of action. All the tested strategies gave on neanids a control over $85 \%$ without statistically differences (Figures 9 and 10).

The effectiveness of sulfoxaflor and Flipper, combined with the favourable toxicological and ecotoxicological profile, and their different mode of action make them extremely interesting tools in the management of resistance and in Integrated Pest Management strategies. In addition, IsoclastTM has proved to have good selectivity towards B. terrestris (Table 2) and predators of mites, whiteflies and trips that allows its use in integrated strategies control (Cocuzza et al., 2018a). Sulfoxaflor, flonicamid and imidacloprid were compared to test the response of $B$. terrestis; an overall survival rate was calculated on the basis of multiple responses (flight, feeding activity etc.) and emphasized the better performance of sulfoxaflor respect to the other two insecticides (Cocuzza et al., 2018b).

\section{Conclusions}

Sulfoxaflor and its commercial products (isoclast ${ }^{\mathrm{TM}}$ Closer $^{\circledR}$ ) are an ideal tool for managing the launches of predatory and parassitoid arthropod species; in fact, integrating the chemical control and the use of useful insects optimizes the whiteflies control as well (Figure 11).

Because certain subpopulations of insects could be controlled by sulfoxaflor that were not controllable with neonicotinoids, the pesticide is especially useful in these situations (Longhurst et al., 2013; Centner et al., 2018).

Small modification in the molecule in sulfoxaflor increased its activity. The observed absence of cross-resistance with other products as imidacloprid further supports its utility. The product is also more stable to UV maintaining its activity above 50\% 10 days after its application and maintains its activity after rain, manifesting an excellent "rainfastness".

Some monooxygenase as Cytochrome P450 are able to degrade some neonicotinoids, it was observed that monooxygenase CYP6G1 is able to degrade also DDT and imidacloprid, but it is incapable of metabolizing sulfoxaflor; this can explain the ability of sulfoxaflor to by-pass cross-resistance of many pest species (Zhu et al., 2011).

In addition, can be of utility to improve the efficacy of spray programs including predatory arthropods species in the rotation for its safe profile against beneficial, pollinators and predatory arthropods (Anh et al., 2016; Serdar Satar et al., 2018).

Unfortunately, the property of sulfoxaflor to by-pass monooxygenase degradation, useful to avoid the insurgence of resistant population, makes the product harmful to useful insects as impollinators.

For this reason, the recommendation is to use the product in a well-integrated managing policy, including a careful management of the landscape, where agroecosystems are planned to be integrated into larger landscapes which include natural ecosystems (Zasada et al., 2017), allowing the development of metacommunities where both specialist and omnivorous natural enemies of pest species are present (Chailleux et al., 2017). 
Table 1. Physical properties and toxicological profiles of neonics and other nAChR agonists and competitive modulators (Casida, 2018). $\mathrm{IC}_{50}$ : ligand concentration that reduces the $\mathrm{ACh}$ induced current by $50 \%, \mathrm{LD}_{50}$ : concentration of ligand that causes the death of $50 \%$.

\begin{tabular}{|c|c|c|c|c|c|c|c|c|c|}
\hline Name & Abbreviation & $\begin{array}{l}\text { nA } \\
\text { Molecular } \\
\text { weight }\end{array}$ & $\begin{array}{l}\mathrm{hR} \mathrm{IC}_{50}(\mathrm{I} \\
\text { Insect } \\
\text { Pest }\end{array}$ & $\begin{array}{l}\text { M)LD } L_{50}(\mathrm{mg} \\
\text { Mammals }\end{array}$ & $\begin{array}{l}\left.\mathrm{kg}^{-1}\right) 48 \mathrm{~h} \\
\text { Ratio } \\
\text { Mammals/ } \\
\text { insects }\end{array}$ & $\begin{array}{c}\text { Honey } \\
\text { beeıg/ } \\
\text { bee }\end{array}$ & Mammal & Bird & Fish \\
\hline \multicolumn{10}{|l|}{ Neonics } \\
\hline Imidacloprid & IMI & 255.7 & 4.3 & 2,600 & 605.0 & 18.0 & 450 & 31 & 211 \\
\hline Clothianidin & CLO & 249.7 & 2.2 & 3,500 & $1,591.0$ & 3.8 & $>5,000$ & $>2,000$ & $>100$ \\
\hline Thimethoxam & TMX & 291.7 & 5,000 & $>100,000$ & $>20.0$ & 5.0 & 1,563 & 1,552 & $>100$ \\
\hline Dinotefuran & DIN & 202.2 & 900 & $>100,000$ & $>111.0$ & 23.0 & 2,400 & $>2,000$ & $>100$ \\
\hline Nithiazine & - & 160.1 & 4,800 & 26,000 & 5.4 & - & 300 & 2,290 & 117 \\
\hline Nitromethylene-IMI & CH-IMI & 253.7 & 0.24 & 210 & 875.0 & - & - & - & - \\
\hline Cycloxaprid & CYC & 308.7 & 43 & 302 & 7.0 & 140.0 & 1,260 & - & - \\
\hline Nitenpyram & NIT & 270.7 & 14 & 49,000 & $3,500.0$ & 140.0 & 1,628 & $>2,250$ & $>1,000$ \\
\hline Thiacloprid & THIA & 252.7 & 2.7 & 860 & 319.0 & 39.0 & 640 & 49 & 31 \\
\hline Acetamiprid & ACET & 222.7 & 8.3 & 700 & 84.0 & 8.1 & 182 & 180 & $>100$ \\
\hline \multicolumn{10}{|c|}{ Other nAChR competitive modulators } \\
\hline Sulfoxaflor & SULF & 277.3 & 265 & - & - & 150.0 & 1,000 & 676 & $>387$ \\
\hline Flupyradifurone & FPF & 288.7 & 2.4 & - & - & 1.2 & $>300$ & 232 & $>74$ \\
\hline \multicolumn{10}{|l|}{ Nicotinoids } \\
\hline (-)-Nicotine & $\mathrm{NIC}$ & 162.2 & 4,000 & 7 & 0.00200 & toxic & $50-60$ & toxic & 4 \\
\hline Epibatidine & EPI & 208.7 & 430 & 0.04 & 0.00009 & - & 0.08 & - & - \\
\hline Desnitro-IMI & DN-IMI & 210.7 & 1,530 & 8.2 & 0.00500 & - & 8.0 & - & - \\
\hline \multicolumn{10}{|l|}{ Mesoionic } \\
\hline Triflumezopyrim & TRIF & 398.3 & 43 & - & - & 0.39 & - & 2,109 & $>100$ \\
\hline
\end{tabular}

Table 2. Species of interest in this review, with notes on distribution, common name, infested plant.

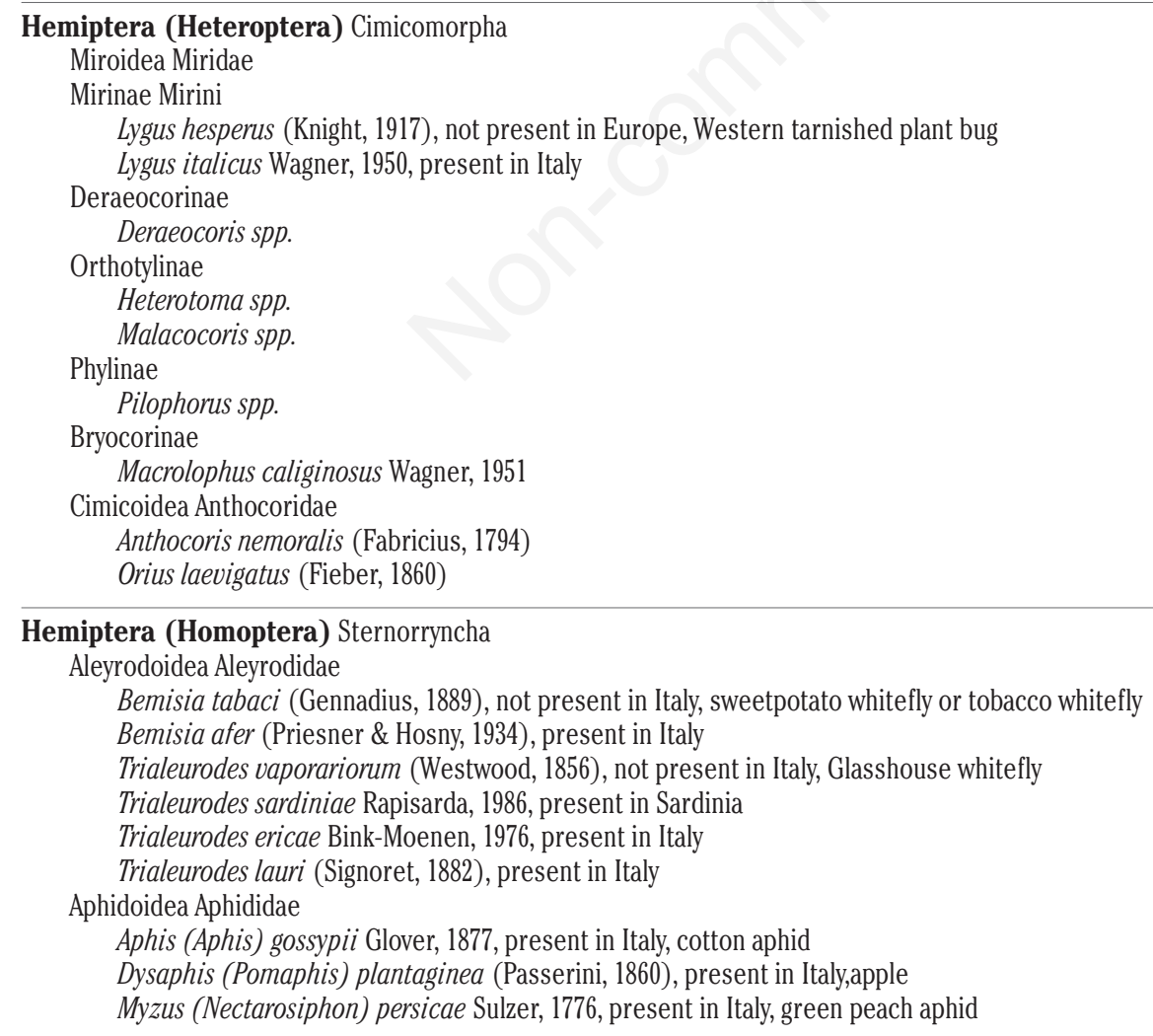


Table 2. Continued from previous page.

Hemiptera (Homoptera) Sternorryncha

Coccoidea Coccidae

Parthenolecanium corni (Bouché, 1844), present in Italy,,vine

Diaspididae Aspidiotini

Aonidiella aurantii (Maskell, 1879), present in Italy, citrus

Diaspidiotus perniciosus (Comstock, 1881), present in Italy, San José scale

Pseudaulacaspis pentagona (Targioni Tozzetti, 1886), present in Italy, Drupaceae

Targionia vitis (Signoret, 1876) present in Italy,vine

Pseudococcidae

Planococcus citri (Risso, 1813), present in Italy,,citrus,

Planococcus ficus (Signoret, 1875), present in Italy,,vine

Pseudococcus comstocki (Kuwana, 1902), present in Ukraina, in Italy (?), Drupaceae

Phylloxeroidea Phylloxeridae

Viteus vitifoliae (Fitch, 1855), [=Daktulosphaira vitifoliae (Fitch, 1856)], present in Italy,,vine

Psylloidea Psyllidae

Diaphorina citri, Kuwayama, 1908, not present in Europe, Asian citrus psyllid

Diaphorina chobauti Puton, 1898, present in Italy

Diaphorina continua Loginova, 1976, present in Sardinia

Diaphorina lycii Loginova, 1978, present in Italy

Diaphorina putonii Low, 1879, present in Sardinia, Sicily

Auchenorryncha Delphacidae

Nilaparvata lugens (Stål, 1854), not present in Europe, brown planthopper

Hymenoptera Apocrita

Chalcidoidea

Eulophidae Tetrastichinae

Tamarixia radiata (Waterstone, 1922), not present in Europe

Tamarixia leptothrix Graham, 1991, present in Italy

Tamarixia monesus (Walker, 1839), present in Italy

Tamarixia tremblayi (Domenichini, 1965), present in Italy

Aphelinidae

Aphytis melinus (DeBach, 1959)

Encyrtidae Apoidea

Anagyrus pseudococci (Girault, 1915)

Apidae

Apis mellifera Linnaeus, 1758,present in Italy

Bombus terrestris (Linnaeus, 1758), present in Italy

Melipona scutellaris Latreille, 1811, not present in Europe, present in Brasil

Ichneumonoidea Braconidae

Aphidius rhopalosiphi de Stefani-Perez, 1902

\section{Neuroptera Hemerobiiformia}

Chrysopidae Chysopinae

Chrysoperla carnea (Stephens, 1836), present in Italy

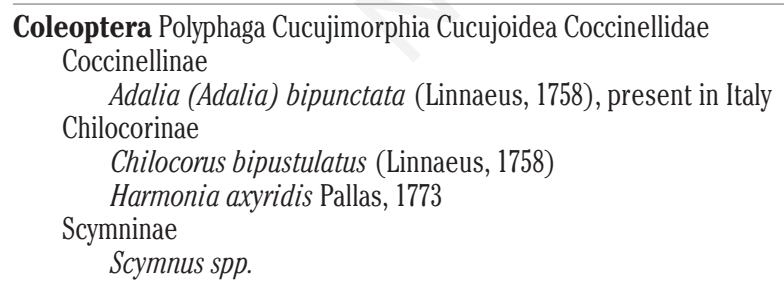

Chelicerata Arachnida Micrura

Megoperculata Araneae

Labidognatha Theridiidae

Latrodectus tredecimguttatus (Rossi, 1790), present in Italy

Latrodectus hesperus Chamberlin \& Ivie, 1935, present in North America

Acari Anactinotrichida

Mesostigmata Dermanissina Ascoidea Phytoseiidae

Amblyseius andersoni (Chant, 1957)

Amblyseius cucumeris (Oudemans, 1930)

Amblyseius swirskii Athias-Henriot, 1962

Phytoseiulus persimilis Athias-Henriot, 1957

Typhlodromus pyri Scheuten, 1857 
Table 3. Mortality $24 \mathrm{~h}$ after the topical application of neonicotinoid insecticides metabolites to the dorsum of the honey bee thorax (Iwasa et al., 2004).

\begin{tabular}{|c|c|c|c|}
\hline Insecticide metabolites & LD50 (ng/bee) & LD50 ( $\mu \mathrm{g} / \mathrm{bee})$ & $95 \% \mathrm{CI}$ \\
\hline Acetamiprid & 7070.0 & 7.0700 & $4.57-11.2$ \\
\hline Imidacloprid & 17.9 & 0.0179 & $0.0092-0.0315$ \\
\hline Thiacloprid & 14600.0 & 14.6000 & $9.53-25.4$ \\
\hline Nitenpyram & 138.0 & 0.1380 & $0.0717-0.259$ \\
\hline Clothianidin & 21.8 & 0.0218 & $0.0102-0.0465$ \\
\hline Dinotefuran & 75.0 & 0.0750 & $0.0628-0.0896$ \\
\hline Thiamethoxam & 29.9 & 0.0299 & $0.0208-0.0429$ \\
\hline
\end{tabular}

Table 4. Laboratory Efficacies of Sulfoxaflor and Imidacloprid on different strains of Sap-Feeding Insects: $\mathrm{LC}_{50}$ in $\mathrm{ppm}\left(\mathrm{mgL}^{-1}\right)$ with fiducial limits in different susceptible and resistant strains; RR: resistance ratio $=\mathbf{L C}_{50}$ resistant strain/LC $\mathrm{L}_{50}$ of susceptible strain $(\mathrm{Zhu}$ et al., 2011).

\begin{tabular}{|c|c|c|c|}
\hline Insecticide & Susceptible strain & Resistant strain & $\mathbf{R R}$ \\
\hline $\begin{array}{l}\text { M. persicae } \\
\text { sulfoxaflor } \\
\text { sulfoximine } \mathbf{2} \\
\text { imidacloprid } \\
\text { Sulfoxaflor } \\
\text { sulfoximine } \mathbf{2} \\
\text { Imidacloprid }\end{array}$ & $\begin{array}{c}0.074(0.049-0.101) \\
0.374(0.199-0.484) \\
0.090(0.07-0.13) \\
4.13(2.25-6.82) \\
62.3(14.5-186.1) \\
0.896(0.620-1.15)\end{array}$ & $\begin{array}{c}1.52(0.644-2.65) \\
12.5(3.44-23.4) \\
15.3(10.62-21.40)\end{array}$ & $\begin{array}{l}0.37 \\
0.20 \\
17.1\end{array}$ \\
\hline $\begin{array}{l}\text { Aphis gossypii } \\
\text { sulfoxaflor } \\
\text { sulfoximine } 2 \\
\text { imidacloprid }\end{array}$ & $\begin{array}{c}0.20(0.015-1.1) \\
3.0(0.6-7.0) \\
7.8(2.4-15.6)\end{array}$ & & \\
\hline $\begin{array}{l}\text { L. hesperus } \\
\text { sulfoxaflor } \\
\text { sulfoximine } 2 \\
\text { imidacloprid }\end{array}$ & $\begin{array}{l}2.78(1.41-4.95) \\
1.69(0.42-3.82) \\
1.32(0.48-2.61)\end{array}$ & & \\
\hline $\begin{array}{l}\text { B. tabaci } \\
\text { sulfoxaflor } \\
\text { sulfoximine } \mathbf{2} \\
\text { imidacloprid } \\
\text { sulfoxaflor } \\
\text { imidacloprid } \\
\text { sulfoxaflor } \\
\text { imidacloprid } \\
\text { sulfoxaflor } \\
\text { imidacloprid } \\
\text { sulfoxaflor } \\
\text { sulfoximine } \mathbf{2} \\
\text { imidacloprid }\end{array}$ & $\begin{array}{c}0.85(0.40-1.5) \\
0.29(0.083-0.66) \\
0.37(0.18-0.63) \\
2.8(1.2-5.5) \\
0.20(0.05-0.55) \\
18(13-24) \\
4.4(2.8-6.1) \\
18(13-24) \\
4.4(2.8-6.1) \\
1.80(0.84-3.13) \\
4.48(2.01-8.16) \\
1.23(0.203-4.17)\end{array}$ & $\begin{array}{c}6.4(2.6-13.1) \\
174(24.6->2000) \\
28(25-55) \\
>1000(-) \\
39(25-55) \\
4500(1900-29000) \\
5.0(3.13-7.76) \\
13.2(7.25-23.2) \\
>1000\end{array}$ & $\begin{array}{c}2.3 \\
870 \\
1.6 \\
>230 \\
2.2 \\
1022 \\
2.8 \\
2.9 \\
>833\end{array}$ \\
\hline
\end{tabular}

Table 5. Insecticidal activity of neonicotinoids on major pests, $\mathrm{LC}_{50}$ and $\mathrm{LC}_{95}$ in $\mathrm{ppm}$ or $\mathrm{mgL}^{-1}$

\begin{tabular}{|c|c|c|c|c|c|c|}
\hline Scientific name & Growth stage & Crop & References & Hours & LC50 (LC95) & Range \\
\hline A. gossypii & $3^{\text {rd }}$ instar larva & Cotton & Gore et al. 2013 & $\begin{array}{l}48 \\
48 \\
72 \\
72\end{array}$ & $\begin{array}{l}1.01 \\
5.85 \\
0.92 \\
4.13\end{array}$ & $\begin{array}{l}- \\
- \\
- \\
-\end{array}$ \\
\hline D. perniciosus & Crawler & Deciduous fruit tree & Buzzetti et al. 2015 & $\begin{array}{l}48 \\
48 \\
48 \\
48 \\
48 \\
48 \\
48 \\
48 \\
48 \\
48\end{array}$ & $\begin{array}{c}2.90 \\
3.10 \\
3.24 \\
3.50 \\
3.56 \\
(44.27) \\
(40.91) \\
(38.82) \\
(39.03) \\
(35.56)\end{array}$ & $\begin{array}{l}(2.59-3.23) \\
(2.79-3.44) \\
(2.92-3.57) \\
(3.17-3.85) \\
(3.23-3.91) \\
(31.20-73.12) \\
(29.60-64.13) \\
(28.70-58.36) \\
(29.19-57.54) \\
(27.22-50.21)\end{array}$ \\
\hline M. persicae & Adult & Many crops & Tang et al. 2015 & 48 & 0.059 & - \\
\hline D. citri & Adult & Citrus & Brar et al. 2017 & 48 & 8.17 & - \\
\hline D. citri & Adult & Citrus & Chen \& Stelinski 2017 & $\begin{array}{l}24 \\
24\end{array}$ & $\begin{array}{c}(797.77) \\
0.80\end{array}$ & $\begin{array}{c}(130.13-16,474.00) \\
(0.26-2.46)\end{array}$ \\
\hline$N$. lugens & $3^{\text {rd }}$ instar & Rice & Liao et al. 2017 & $\begin{array}{l}96 \\
96\end{array}$ & $\begin{array}{l}1.63 \\
13.2\end{array}$ & - \\
\hline
\end{tabular}


Table 6. Activity of sulfoxaflor compared with commercial sap-feeding insecticides for the control of green peach aphid and cotton aphid in laboratory bioassays, $\mathrm{LC}^{50}$ in $\mathrm{ppm}$ or $\mathrm{mgL}^{-1}$.

\begin{tabular}{lcc} 
& M. persicae & A.gossypit \\
Sulfoxaflor & LC $_{50}(95 \% \mathrm{CI})$ & LC $_{50}(95 \%$ CI $)$ \\
Imidacloprid & $0.05(0.02-0.09)$ & $0.2(0.015-1.1)$ \\
\hline Acetamiprid & $0.09(0.07-0.13)$ & $7.8(2.4-15.6)$ \\
Thiamethoxam & $0.07(0.03-0.12)$ & $5.8(1.1-12.3)$ \\
\hline Dinotefuran & $0.05(0.03-0.08)$ & $0.6(0.09-2.0)$ \\
Flonicamid & $1.76(0.87-4.48)$ & $40(30-60)$ \\
\hline Spirotetramat & $0.76(0.26-7.16)$ & $80(50-140)$ \\
\hline
\end{tabular}

Table 7. Activity of sulfoxaflor compared with commercial sap-feeding insecticides for the control of sweetpotato whitefly and western tarnished plant bug in laboratory bioassays $\mathrm{LC}_{50}$ in $\mathrm{ppm}$ or $\mathrm{mgL}^{-1}$.

\begin{tabular}{lcc} 
& B. tabaci & Lygus hesperus \\
Sulfoxaflor & $\mathrm{LC}_{50}(95 \% \mathrm{CI})$ & $2.78(1.41-4.95)$ \\
Imidacloprid & $1.29(0.76-2.08)$ & $1.23(0.48-2.61)$ \\
\hline Acetamiprid & $0.64(0.32-1.11)$ & $7.42(2.73-30.47)$ \\
Thiamethoxam & $0.04(0.02-0.08)$ & $0.09(0.002-0.36)$ \\
\hline Dinotefuran & $0.20(0.11-0.34)$ & $4.95(2.66-8.90)$ \\
Flonicamid & $0.13(0.07-0.23)$ & $>200$ \\
\hline Spirotetramat & $>200$ & $>200$ \\
\hline
\end{tabular}

Table 8. Risk mitigation measures incorporated in the registration of sulfoxaflor to minimize damages to bees (Centner et al., 2018).

\begin{tabular}{|c|c|c|c|}
\hline Measure & Benefit & Limitation & Potential for harm \\
\hline $\begin{array}{l}\text { No application until after } \\
\text { petal fall }\end{array}$ & $\begin{array}{l}\text { Pollinators gone before } \\
\text { applications }\end{array}$ & $\begin{array}{l}\text { Doesn't cover situations } \\
\text { with blooming weeds }\end{array}$ & $\begin{array}{l}\text { Pollinator Stewardship Council (2015); } \\
\text { Center for Biological Diversity (2016) }\end{array}$ \\
\hline 12-foot buffer & $\begin{array}{l}\text { Keeps spray drift away from } \\
\text { pollinators }\end{array}$ & $\begin{array}{l}\text { Offers little protection against } \\
\text { chronic risks }\end{array}$ & Center for Biological Diversity (2016) \\
\hline Permissible tank mixes & $\begin{array}{c}\text { Prevents unknown detrimental } \\
\text { effects }\end{array}$ & $\begin{array}{l}\text { Insufficient information on } \\
\text { synergistic effects }\end{array}$ & $\begin{array}{l}\text { Center for Biological } \\
\text { Diversity (2016) }\end{array}$ \\
\hline $\begin{array}{l}\text { Nozzle size and height } \\
\text { of sprayer }\end{array}$ & $\begin{array}{c}\text { Reduces drift from harming } \\
\text { off property pollinators }\end{array}$ & $\begin{array}{l}\text { No consideration of other } \\
\text { drift reduction technologies }\end{array}$ & Palardy and Centner (2017) \\
\hline
\end{tabular}

Table 9. Acute toxicity values of imidacloprid for M. scutellaris (Table 2, Costa et al., 2015).

\begin{tabular}{lcccccc} 
Exposure mode & Tlime (hours) & LD & LC & & $\chi^{20}$ & D.I.95\% \\
Topicng a.i/bee & 24 & 2.41 & - & 1.6303 .270 & 0.753 & 4 \\
& 48 & 1.29 & - & $0.813-1.903$ & 2.642 & 4 \\
Ingestionng a.i. diet $\mathrm{L}^{-1}$ & 24 & - & 2.01 & $1.551-2.618$ & 2.534 & 4 \\
& 48 & - & 0.81 & $0.264-1.538$ & 4.001 & 4 \\
\hline
\end{tabular}

$\left(L D^{50}\right)$ mean lethal dose; $\left(L^{50}\right)$ mean lethal concentration; (C.I. 95\%) confidence interval 95\%; ( $\left.\chi^{2}\right)$ chi-square, and (D.F.) degree of freedom.

Table 10. Clothianidin, Imidacloprid and Thiamethoxam: acute oral toxicity $\mathrm{LD}_{50}$ expressed as ng/bee at 24 , 48 , and 72 hours for different subspecies species of A. mellifera (Table 2; Laurino et al., 2013).

\begin{tabular}{|c|c|c|c|c|c|c|c|c|c|c|c|c|}
\hline \multirow[t]{2}{*}{ Hive } & \multirow[t]{2}{*}{ Subspecies } & \multirow[t]{2}{*}{ Geographic origin } & \multirow[t]{2}{*}{ Strain } & \multicolumn{3}{|c|}{ Clothianidin } & \multicolumn{3}{|c|}{ Imidacloprid } & \multicolumn{3}{|c|}{ Thiamethoxam } \\
\hline & & & & $24 \mathrm{~h}$ & $48 \mathrm{~h}$ & $72 \mathrm{~h}$ & $24 \mathrm{~h}$ & $48 \mathrm{~h}$ & $72 \mathrm{~h}$ & $24 \mathrm{~h}$ & $48 \mathrm{~h}$ & $72 \mathrm{~h}$ \\
\hline ligl & A.m. ligustica & Piedmont (Italy) & A & 1.24 & 1.11 & 1.25 & & & & 4.32 & 3.90 & 3.59 \\
\hline lig2 & A.m. ligustica & Piedmont (Italy) & A & 2.75 & 2.82 & 2.79 & 99.82 & 34.37 & 29.70 & 2.26 & 2.31 & 2.15 \\
\hline lig3 & A.m. ligustica & Piedmont (Italy) & A & 5.37 & 5.07 & 4.83 & 170.52 & 85.47 & 65.14 & 5.01 & 5.06 & 4.52 \\
\hline lig4 & A.m. ligustica & Piedmont (Italy) & A & & & & & & & 4.13 & 3.68 & 4.27 \\
\hline lig5 & A.m. ligustica & Piedmont (Italy) & B & 2.85 & 2.61 & 2.50 & 83.97 & 28.81 & 24.96 & 2.48 & 2.44 & 2.44 \\
\hline lig6 & A.m. ligustica & Piedmont (Italy) & $\mathrm{C}$ & 2.20 & 2.19 & 2.16 & 120.65 & 59.36 & 34.96 & 1.99 & 1.65 & 1.64 \\
\hline mell & A. m. mellifera & South-East France & $\mathrm{D}$ & 6.76 & 6.27 & 6.13 & & 242.45 & 193.59 & 3.40 & 3.40 & 3.36 \\
\hline carla & A. m. carnica & Croatia & $\mathrm{E}$ & & & & & & & 9.00 & 9.07 & 8.86 \\
\hline carlb & A. m. carnica & Croatia & E & & & & & & & 5.73 & 5.56 & 5.46 \\
\hline car2 & A. m. carnica & Croatia & $\mathrm{E}$ & & & & & & & 5.71 & 5.64 & 5.36 \\
\hline
\end{tabular}


Table 11. $\mathrm{LD}_{50}$ values (ng/bee) at the different times for the three active ingredients (Laurino et al., 2010).

Clothianidin

\begin{tabular}{lccc}
$24 \mathrm{~h}$ & 4.930 & 3.885 & 4.627 \\
$48 \mathrm{~h}$ & 4.671 & 3.789 & 4.507 \\
$72 \mathrm{~h}$ & 4.514 & 3.747 & 4.369 \\
Imidacloprid & & & 187.208 \\
$24 \mathrm{~h}$ & 191.044 & 173.088 & 109.579 \\
$48 \mathrm{~h}$ & 99.063 & 103.705 & 97.425 \\
$72 \mathrm{~h}$ & 74.631 & 46.763 & 4.546 \\
Thiametoxam & & & 4.383 \\
$24 \mathrm{~h}$ & 2.761 & 3.336 & 3.151 \\
$48 \mathrm{~h}$ & 2.644 & 3.018 & \\
$72 \mathrm{~h}$ & 2.556 & 2.936 & \\
\hline
\end{tabular}

Table 12. Acute toxicity of sulfoxaflor (IsoclastTM) for bees (Dow AgroSciences, 2017).

\begin{tabular}{lcc} 
Isoclast Active & Acute oral toxicity & Acute toxicity by contact exposure \\
Honeybee (Apis mellifera) & & \\
Technical $(95.6 \%$ a.i. & $\mathrm{LD}_{50}(48 \mathrm{~h})=146 \mathrm{ng}$ a.i./bee & $\mathrm{LD}_{50}(72 \mathrm{~h})=379 \mathrm{ng}$ a.i./bee \\
Formulation SC & $\mathrm{LD}_{50}(48 \mathrm{~h})=65 \mathrm{ng}$ a.i./bee & $\mathrm{LD}_{50}(48 \mathrm{~h})=283 \mathrm{ng}$ a.i./bee \\
$\begin{array}{l}\text { Bumble bee }(\text { Bombus terrestris }) \\
\text { Formulation SC }\end{array}$ & $\mathrm{LD}_{50}(72 \mathrm{~h})=27 \mathrm{ng}$ a.i./bee & $\mathrm{LD}_{50}(72 \mathrm{~h})=7554 \mathrm{ng}$ a.i./bee \\
\hline
\end{tabular}

Table 13. Effect of sulfoxaflor on beneficial arthropods (Dow Agro Sciences, 2017).

\begin{tabular}{|c|c|c|c|c|c|c|c|}
\hline Family & IOBC* & Beneficial arthropod & Assays number & Type & Exposure & Rate (gai/ha) & Notes \\
\hline Phytoseiidae & $\begin{array}{c}1-2 \\
1 \\
1 \\
1 \\
1\end{array}$ & $\begin{array}{l}\text { Amblyseius andersoni } \\
\text { Amblyseius cucumeris } \\
\text { Amblyseiusswirskii } \\
\text { Phytoseiulus persimilis } \\
\text { Typhlodromus pyri }\end{array}$ & $\begin{array}{l}3 \\
1 \\
5 \\
2 \\
5\end{array}$ & $\begin{array}{l}\text { F } \\
\text { Lab } \\
\text { G } \\
\text { Lab } \\
\text { F }\end{array}$ & $\begin{array}{l}\text { Fresh residue } \\
\text { Topical } \\
\text { Freshr esidue } \\
\text { Topical }\end{array}$ & $\begin{array}{l}\text { Topical } \\
24-48 \\
24 \\
24-48 \\
24-48\end{array}$ & $\begin{array}{c}24-48 \\
\text { Adults } \\
\text { LAB (48 gai/ha)-IOBC Class: } 1 \\
\text { LAB (48 gai/ha)-IOBC Class: } 1\end{array}$ \\
\hline Coccinellidae & $\begin{array}{c}2-3 \\
2 \\
2\end{array}$ & $\begin{array}{l}\text { Chilocorusbipustulatus } \\
\text { Harmonia axyridis } \\
\text { Scymnus spp. }\end{array}$ & $\begin{array}{l}1 \\
1 \\
1\end{array}$ & $\begin{array}{l}F \\
F \\
F\end{array}$ & $\begin{array}{l}\text { Topical } \\
\text { Topical } \\
\text { Topical }\end{array}$ & $\begin{array}{c}36-48 \\
24 \\
24 \\
\end{array}$ & \\
\hline $\begin{array}{l}\text { Chrysopidae } \\
\text { Miridae }\end{array}$ & $\begin{array}{l}1 \\
2 \\
2 \\
2 \\
2 \\
1 \\
2\end{array}$ & $\begin{array}{l}\text { Chrisoperlacarnea } \\
\text { Deraeocoris spp. } \\
\text { Heterotoma spp. } \\
\text { Malacoris spp. } \\
\text { Pilophorus spp. } \\
\text { Macrolophus caliginosus } \\
\text { Macrolophus caliginosus }\end{array}$ & $\begin{array}{l}3 \\
1 \\
1 \\
1 \\
1 \\
1 \\
1 \\
1\end{array}$ & $\begin{array}{c}\text { Lab } \\
F \\
F \\
F \\
F \\
\text { Lab } \\
F\end{array}$ & $\begin{array}{c}\text { Fresh residue } \\
\text { Topical } \\
\text { Topical } \\
\text { Topical } \\
\text { Topical } \\
\text { Fresh residue } \\
\text { Topical } \\
\end{array}$ & $\begin{array}{c}24-48 \\
24 \\
24 \\
24 \\
24 \\
24-48 \\
24\end{array}$ & Larvae \\
\hline Anthocoridae & $\begin{array}{c}1-2 \\
2-3 \\
1 \\
1\end{array}$ & $\begin{array}{l}\text { Anthocoris nemoralis } \\
\text { Anthocoris nemoralis } \\
\text { Orius laevigatus } \\
\text { Orius laevigatus }\end{array}$ & $\begin{array}{l}1 \\
1 \\
2 \\
1\end{array}$ & $\begin{array}{c}F \\
F \\
\text { Lab } \\
G\end{array}$ & $\begin{array}{c}\text { Topical } \\
\text { Topical } \\
\text { Fresh residue } \\
\text { Dry residue }\end{array}$ & $\begin{array}{c}24-48 \\
24-36 \\
24-48 \\
24\end{array}$ & $\begin{array}{c}\text { Adults } \\
\text { Larvae } \\
\text { Release } 3 \text { days after applic. }\end{array}$ \\
\hline Aphelinidae & 2 & Aphytis melinus & 1 & Lab Ext. & Dry residue & $24-48$ & Adults \\
\hline Encyrtidae & 1 & Anagyruspseudococci & 1 & $\mathrm{~F}$ & Topical & 48 & Parasitism $>20 \%$ \\
\hline Braconidae & 2 & Aphidiusrhopalosiphi & 1 & Lab & Dry residue & $24-48$ & Release 14 days after applic. \\
\hline
\end{tabular}

*IOBC (International Organization Biological Control) classification as follows. Harmless = 1 (Labtest <30\%; Semi-field and field test <25\%); Slightly harmful = 2 (Labtest 30-75\%; Semi-field and field test 25-50\%); Moderately harmful $=3$ (Labtest 76-99\%; Semi-field and field test 51-75\%); Harmful = 4 (Labtest >99\%; Semi-field and field test > 75\%). F: Field; Lab: Laboratory; G.: Greenhouse. Assessment: Field and greenhouse, 2-7 days after treatment; Lab, 1-7 days of exposure; LAB Ext. 7 days after treatment. 
Table 14. Toxicological profile in mammals (Dow AgroSciences, 2017).

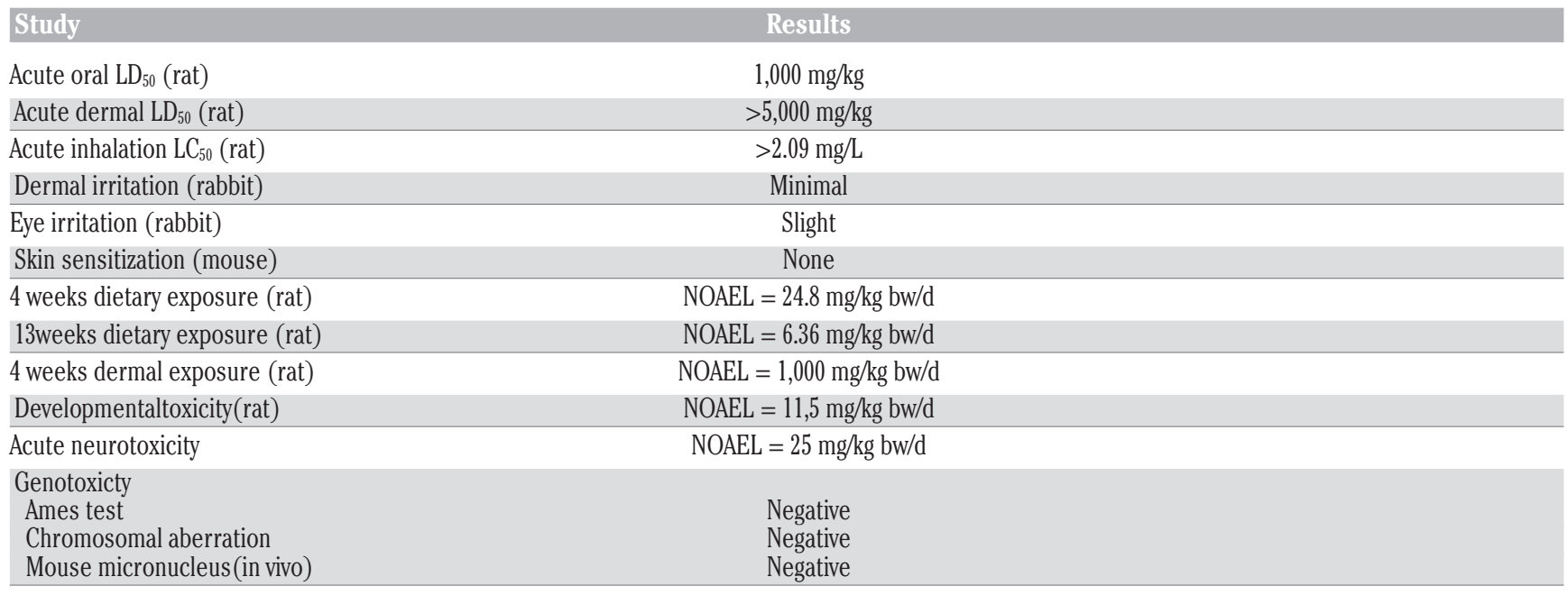

Table 15. Details of the trials carried out between 2015-2017.

\begin{tabular}{lccc}
\hline Trials & Year & Region & Species \\
1 & 2015 & Lazio & T. vaporariorum \\
2 & 2015 & Lazio & T. vaporariorum \\
\hline 3 & 2015 & Sicilia & B. tabaci \\
4 & 2016 & Lazio & T. vaporariorum \\
\hline 5 & 2017 & Sicilia & B. tabaci \\
6 & 2017 & Sicilia & B. tabaci \\
\hline 7 & 2017 & Lazio & T. vaporariorum \\
\hline
\end{tabular}

Table 16. Characteristics of the formulations used in the trials.

\begin{tabular}{|c|c|c|c|c|}
\hline Treatment name & Active substance & $\begin{array}{c}\text { Conc. of active subs } \\
\% \mathrm{~g} / \mathrm{L} \mathrm{g} / \mathrm{Kg}\end{array}$ & Formulation type & Treatment rate \\
\hline Closer & Isoclast $^{\mathrm{TM}}$ & 120 & $\mathrm{SC}$ & 200/400 mL/ha \\
\hline Teppeki & Flonicamid & 500 & WG & $0.1-0.12 \mathrm{Kg} / \mathrm{ha}$ \\
\hline Movento & Spirotetramat & 48 & $\mathrm{SC}$ & 1.5/2.0 L/ha \\
\hline Flipper & Fatty acid & 73 & $\mathrm{EC}$ & $1 \% \mathrm{VN}$ \\
\hline Codacide & Rapeseed oil & & $\mathrm{L}$ & $2.5 \mathrm{~L} / \mathrm{ha}$ \\
\hline
\end{tabular}

Table 17. Description of the two strategies experimented between 2015 and 2017 for T. vaporariorum and B. tabaci.

\begin{tabular}{|c|c|c|c|}
\hline Treatment number & Treatment name & Application timing & Treatment rate (mL or Kg/ha) \\
\hline 1 & Isoclast $^{\mathrm{TM}}$ & $\mathrm{A}$ & 200 \\
\hline 1 & Colza oil & A & 2500 \\
\hline 1 & Flonicamid & B & 0.1 \\
\hline 1 & Isoclast $^{\mathrm{TM}}$ & $\mathrm{C}$ & 200 \\
\hline 1 & Colza oil & $\mathrm{C}$ & 2500 \\
\hline 1 & Flonicamid & $\mathrm{D}$ & 0.1 \\
\hline 1 & Flipper & E & $1 \% \mathrm{v} / \mathrm{v}$ \\
\hline 2 & Isoclast $^{\mathrm{TM}}$ & A & 200 \\
\hline 2 & Codacide oil & $\mathrm{A}$ & 2500 \\
\hline 2 & Spirotetramat & B & 2000 \\
\hline 2 & Isoclast $^{\mathrm{TM}}$ & $\mathrm{C}$ & 200 \\
\hline 2 & Colza oil & $\mathrm{C}$ & 2500 \\
\hline 2 & Spirotetramat & $\mathrm{D}$ & 2000 \\
\hline 2 & Flipper & E & $1 \% \mathrm{v} / \mathrm{v}$ \\
\hline 3 & Untreated & & \\
\hline
\end{tabular}




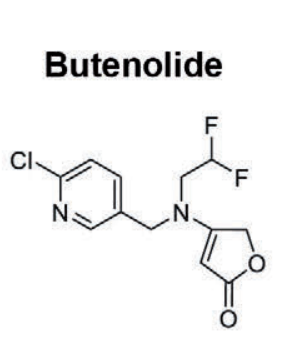

Flupyradiferone (FPF)

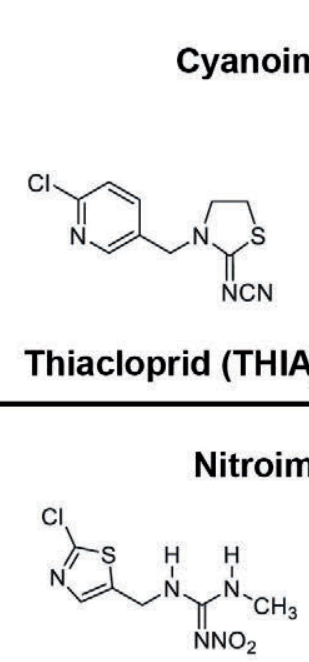

Clothianidin (CLO)

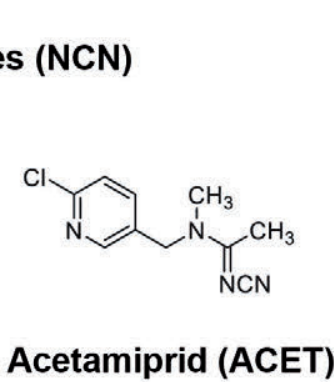

Mesoionic

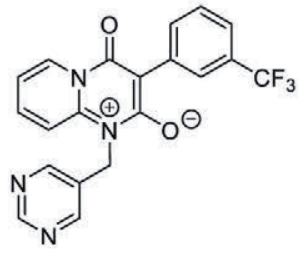

Triflumezopyrim (TRIF)<smiles>O=[N+]([O-])C1CNCCN1Cc1ccc(Cl)nc1</smiles>

Imidacloprid (IMI)

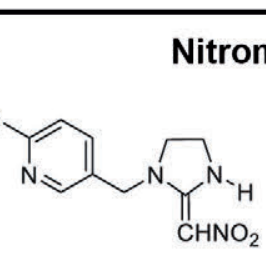

Nitromethylenes (CHNO2)<smiles></smiles>

Nithiazine

Nitromethylene-IMI(CH-IMI)<smiles>CC1=C2C([N+](=O)[O-])C1CC1N(Cc3ccc(Cl)nc3)CCN21</smiles>

Cycloxaprid(CYC)<smiles>CNC(NCC1CCOC1)=[N+]([O-])[O-]</smiles>

Dinotefuran (DIN)<smiles>CN1COCN(Cc2cnc(Cl)s2)C1=[N+]([O-])O</smiles>

Thiamethoxam (TMX)<smiles>CCN(Cc1ccc(Cl)nc1)/C(=C/[N+](=O)[O-])NC</smiles>

Nitenpyram(NIT)

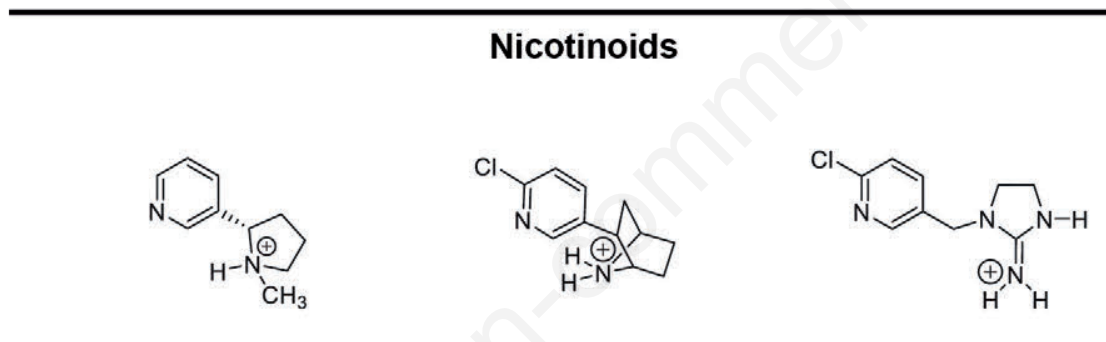

Nicotine (NIC)
Epibatidine (EPI)

\section{Sulfoximine}

$\mathrm{CF}_{3}$<smiles>CC(c1ccc(Br)nc1)S(C)(=N)=O</smiles>

\section{Sulfoxaflor (SULF)}

Cyanoimines (NCN) Nitroimines (NNO2)<smiles>C/C(=N\N)N(C)Cc1ccc(Cl)nc1</smiles>

Acetamiprid<smiles>N#CN=C1SCCN1Cc1ccc(Cl)nc1</smiles><smiles>CNC(=N[N+](=O)[O-])NCc1cnc(Cl)s1</smiles>

Clothianidin<smiles>O=[N+]([O-])/N=C1\NCCN1Cc1ccc(Cl)nc1</smiles><smiles>CNC(=N[N+](=O)[O-])NCC1CCOC1</smiles>

Dinotefuran<smiles>CN1COCN(Cc2cnc(Cl)s2)/C1=N/[O+]([O-])[O-]</smiles>

Thiamethoxam<smiles>CC(c1ccc(C(F)(F)F)nc1)S(C)(=O)=NC#N</smiles>

Isoclast

Figure 1. Chemical formula of sulfoxaflor and some neonicotinoids. 


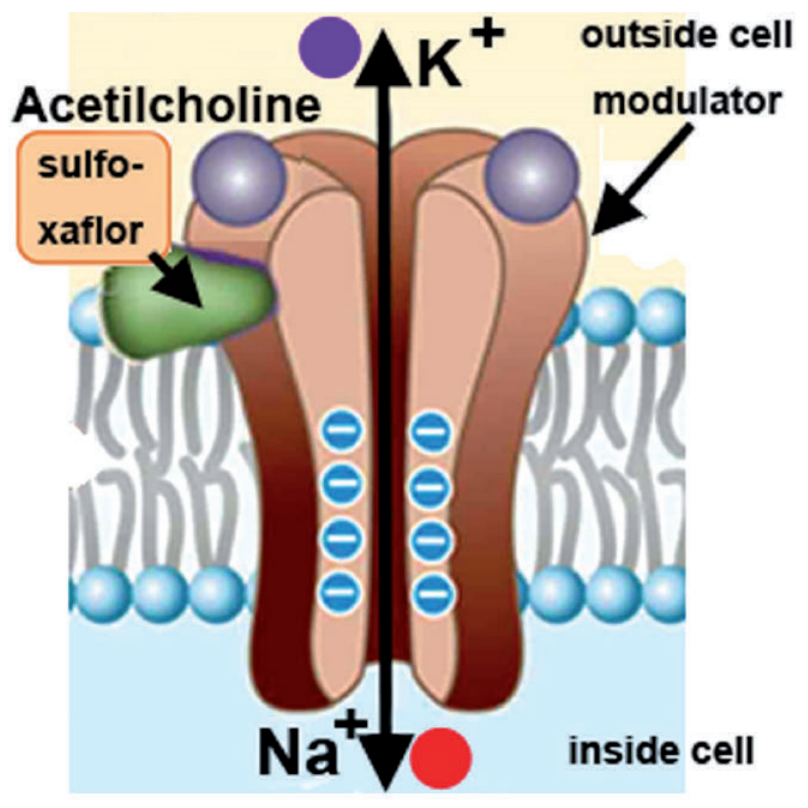

Figure 2. Action of sulfoxoflor on nicotinic receptors Nicotinic acetylcholine receptor ( $\mathrm{AAChR}$ ) agonist insecticide target in insect cation channel excitatory synapse.

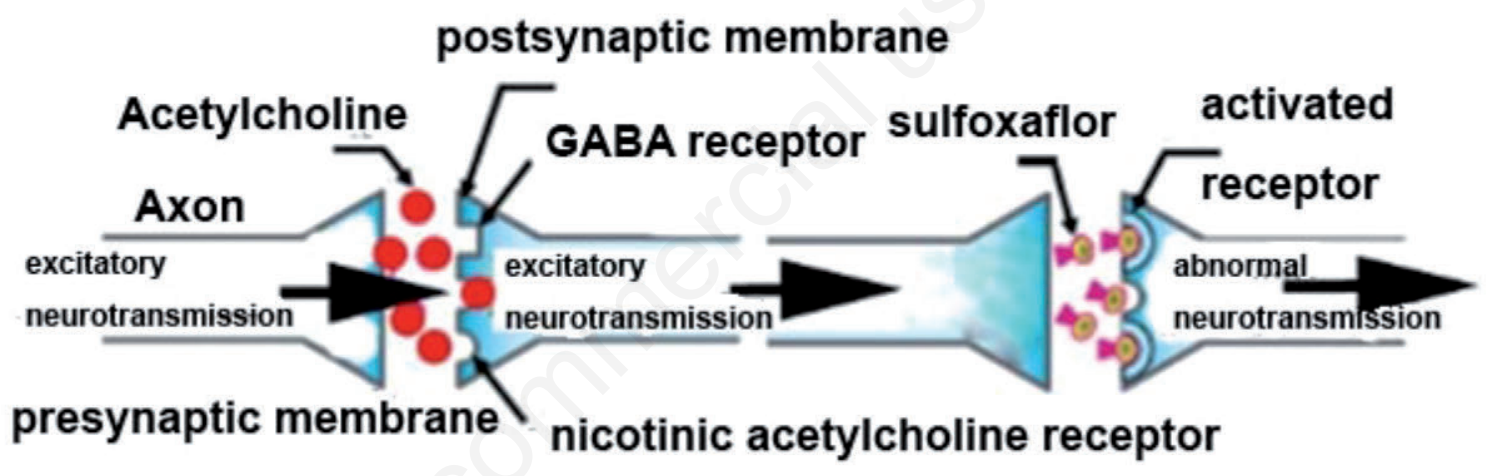

Figure 3. Mechanism of transmission along the synapsis.

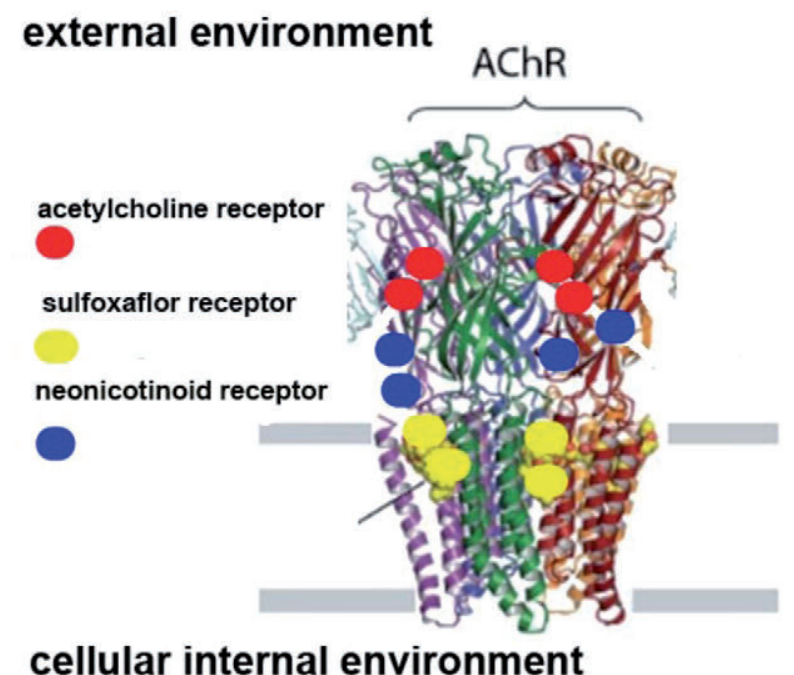

Figure 4. Hypothetic structure of AChR receptor ligating acetylcholine, neonicotinoids, sulfoxaflor. 

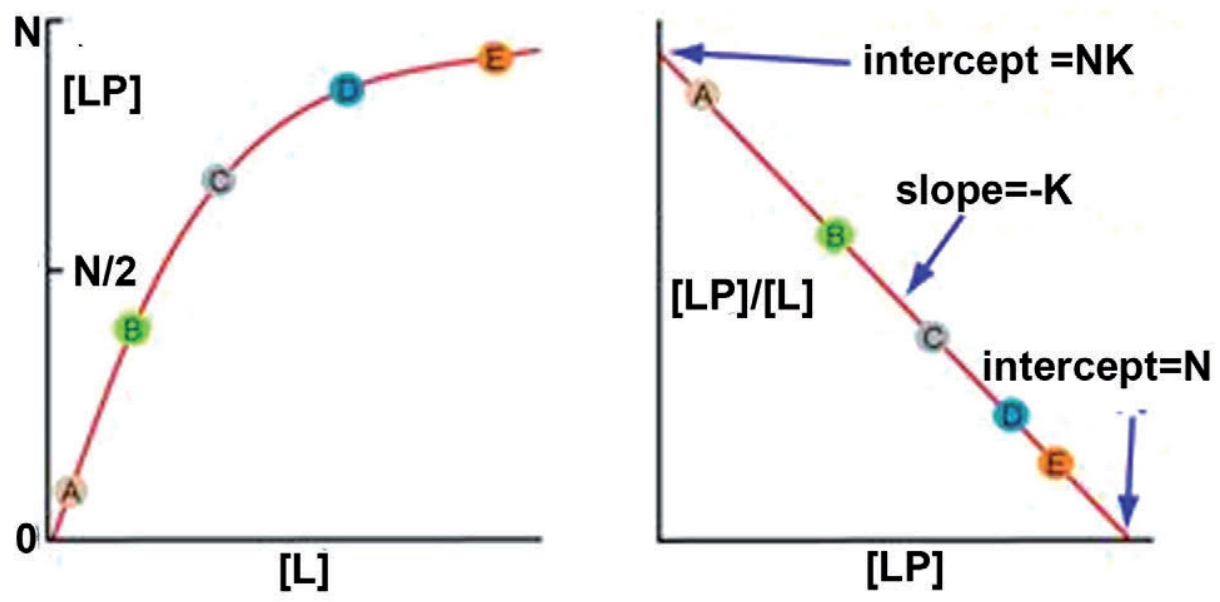

Figure 5. On the left relation between unbound insecticide concentration $[\mathrm{L}]$ and number of bound sites [LP], on the right the linearization of the equation called Scatchard equation.

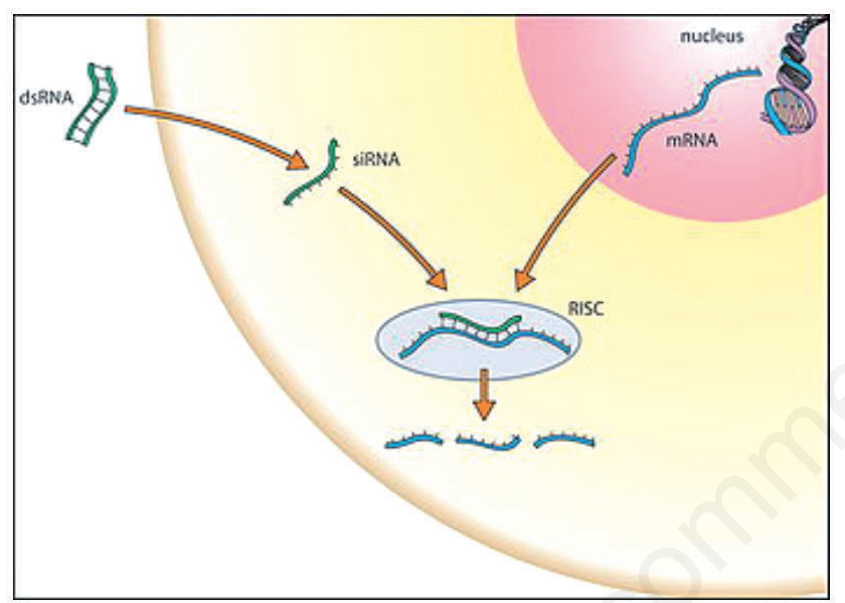

Figure 6. dsRNA action on nuclear receptors NR.

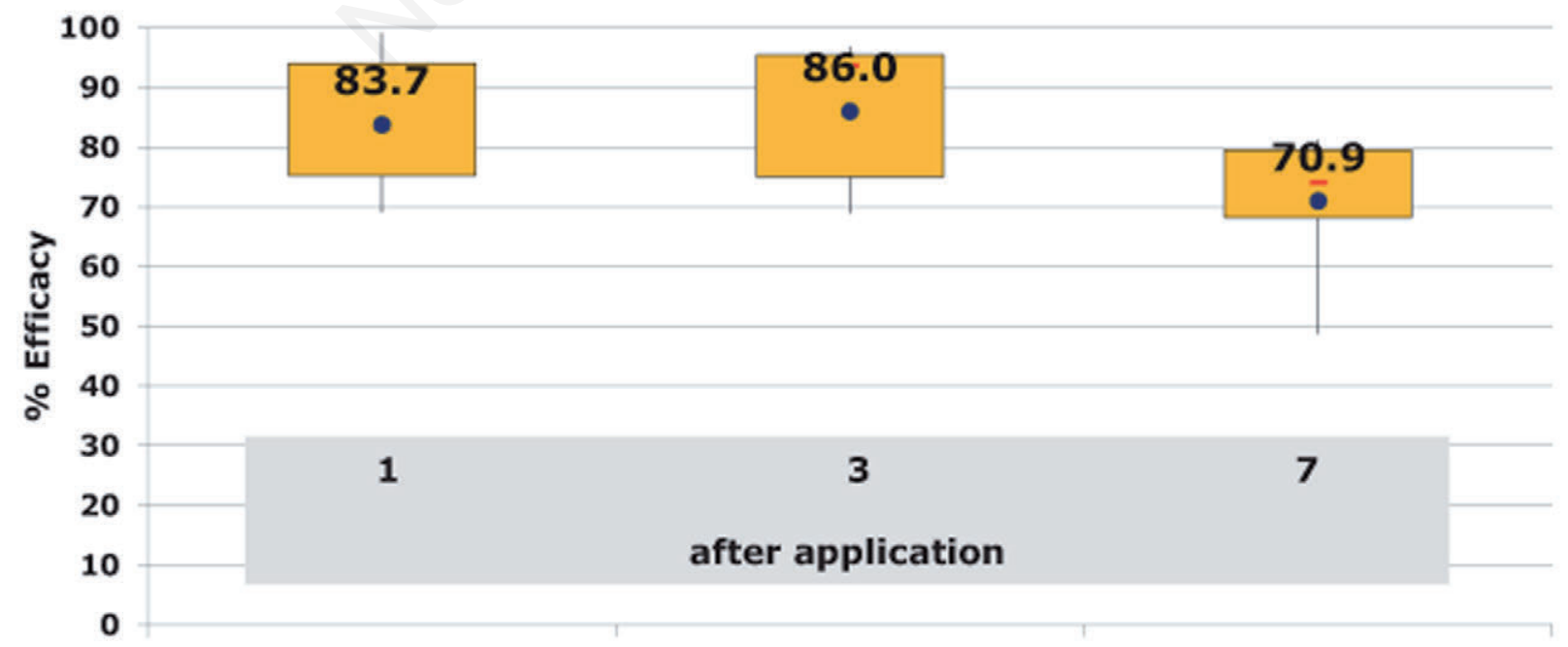

Figure 7. Isoclast ${ }^{\mathrm{TM}} 24 \mathrm{~g}$ ai/ha: efficacy \% on adults of $B$. tabaci and $T$. vaporariorum after 1,3,7 day of application. 


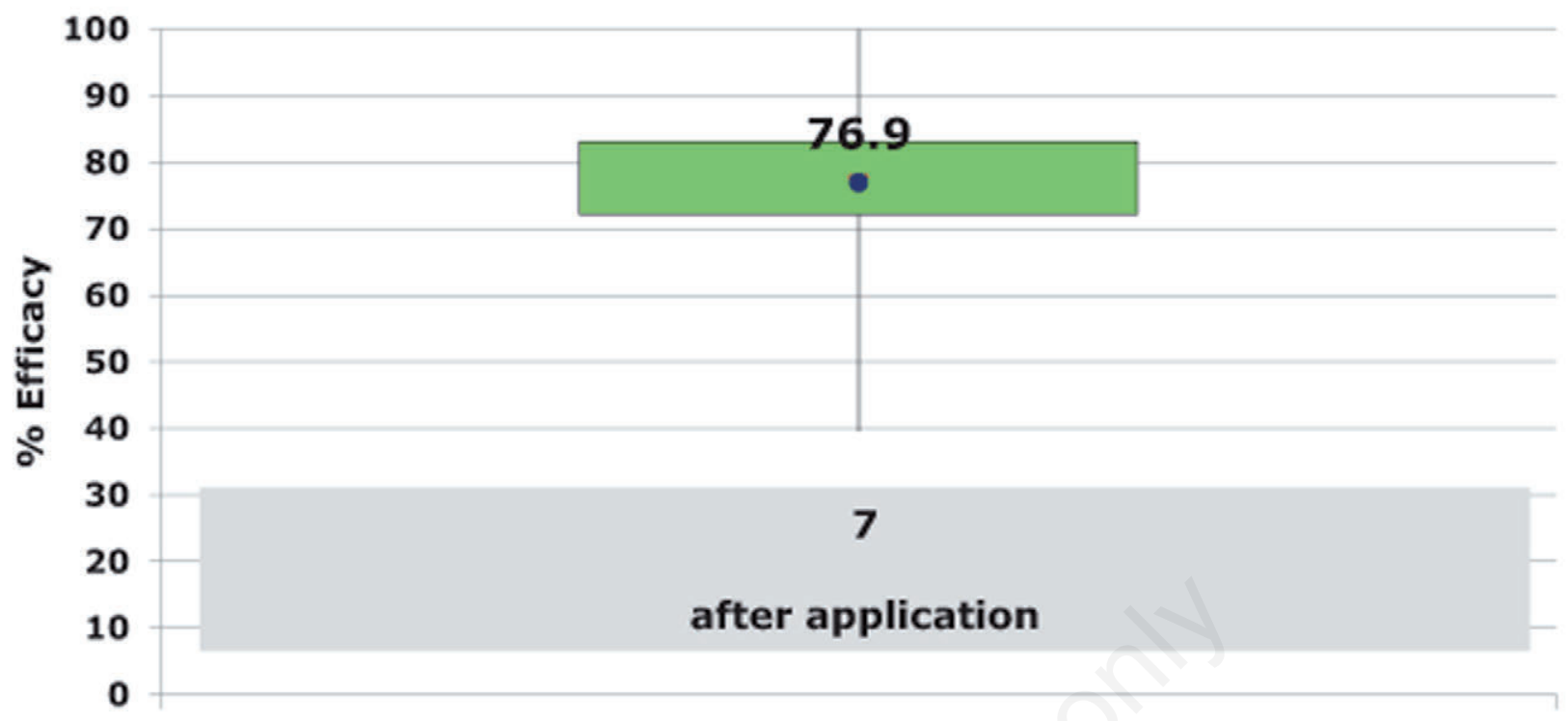

Figure 8. Isoclast ${ }^{\mathrm{TM}} 24 \mathrm{~g}$ ai/ha: efficacy $\%$ on neanids of $B$. tabaci and T. vaporariorum after 7 day of application.

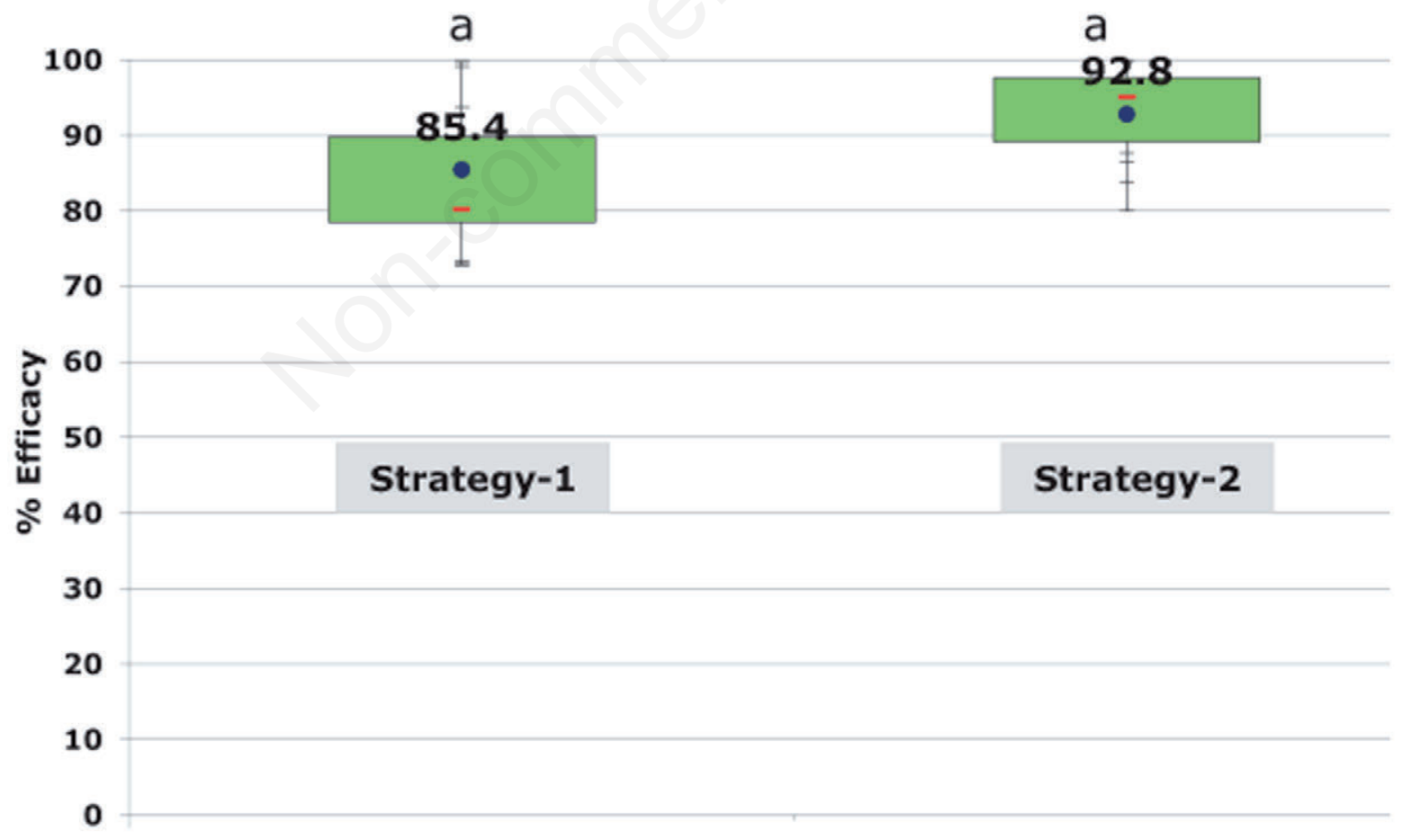

Figure 9. Isoclast ${ }^{\mathrm{TM}} 24 \mathrm{~g}$ ai/ha: efficacy $\%$ on adults of B. tabaci and T. vaporariorum after 7 day of application. 
a

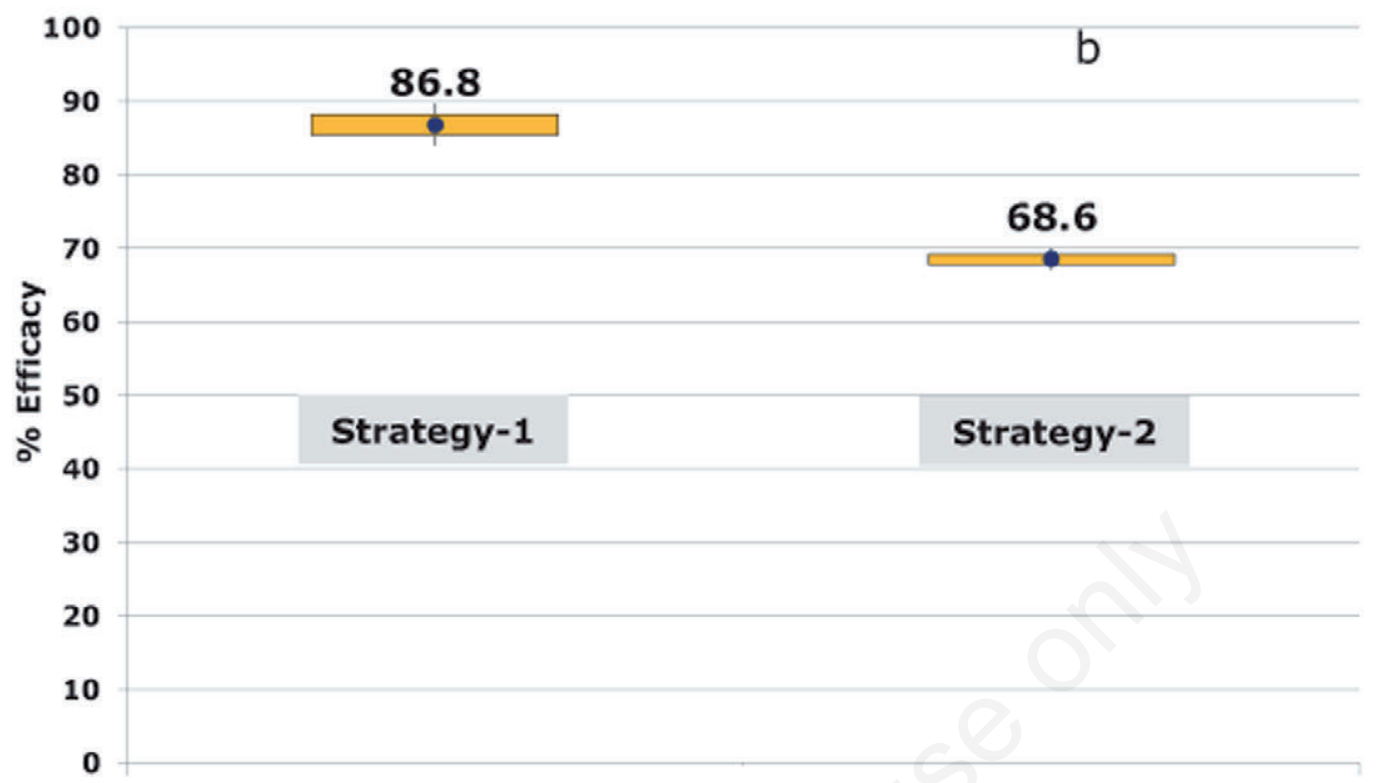

Figure 10. Isoclast ${ }^{\mathrm{TM}} 24 \mathrm{~g}$ ai/ha: efficacy $\%$ on neanids of $B$. tabaci and T. vaporariorum after 7 day of application.
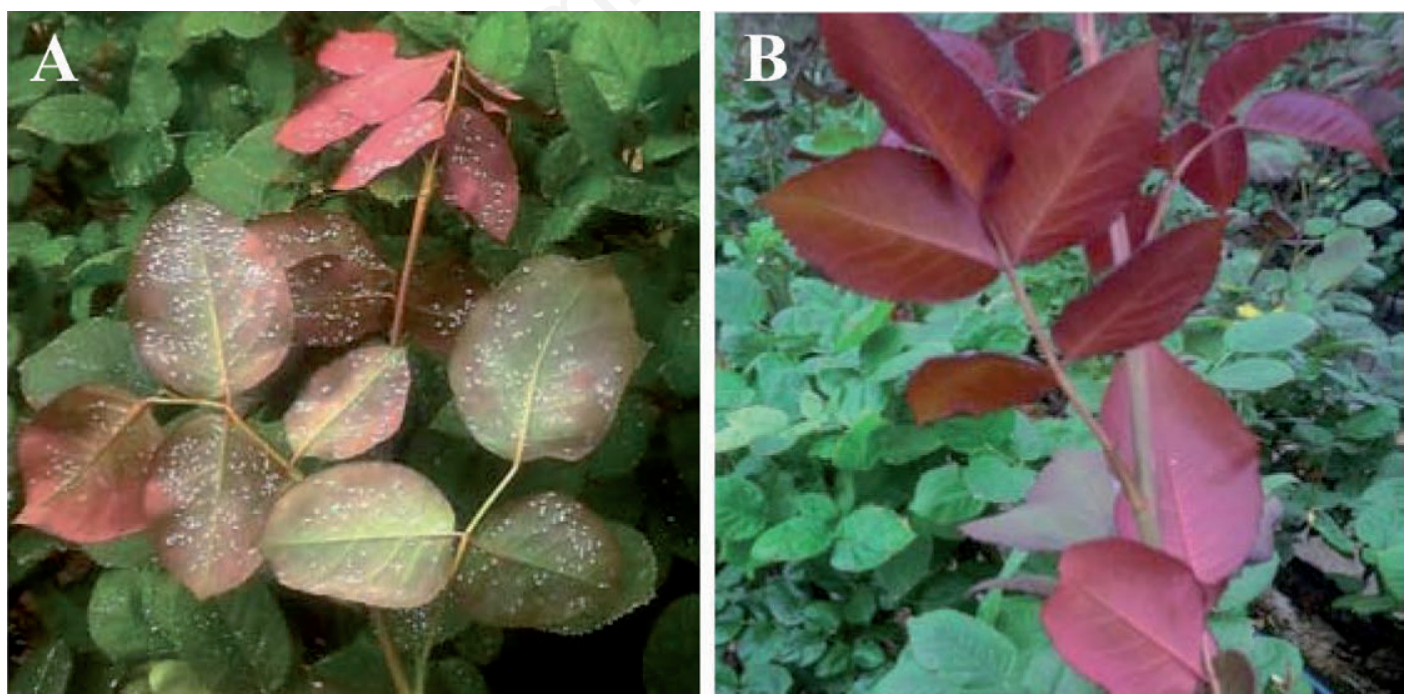

Figure 11. Isoclast ${ }^{\mathrm{TM}}$ : Knockdown effect on $T$. vaporariorum, adults (A) before the treatments (B) sulfoxaflor (48 $\mathrm{g}$ ai/ha) after 24 hours. 


\section{References}

AHMAD H., ARIF M. I., NAVEED M., 2010 - Dynamics of resistance to organophosphate and carbamate insecticides in the cotton whitefly Bemisia tabaci (Hemiptera: Aleyrodidae) from Pakistan. - J. Pest. Sci. 83: 409-420.

ANH K.T., ALVES T.M., KOCH R.L., 2016 - Potential for Sulfoxaflor to Improve Conservation Biological Control of Aphis glycines (Hemiptera: Aphididae) in Soybean. - J. Econ. Entomol. 109: 2105-2114.

BABCOCK J.M., GERWICK CB., HUANG JX., LOSO MR., NAKAMURA G., NOLTING SP., ROGERS RB., SPARKS T.C., THOMAS J., WATSON GB., ZHU YM., 2011 Biological characterization of sulfoxaflor, a novel insecticide. - Pest Manag. Sci. Back. 67: 328-334.

BACCI L., CRIVELLI L., CONVERTINI S., D'ASCENZO D., 2018a - Acquisizioni preliminari per il contenimento di infestazioni di fillossera della vite con sulfoxaflor (isoclast ${ }^{\mathrm{tm}}$ ) in Abruzzo - Atti Giornate Fitopatologiche, 2018

BACCI L., FENIO A., CONVERTINI S., 2018b - IPM strategy for white fly insecticides in European greenhouse of tomato. ECE2018 XI European Congress Entomology Naples 26/July/2018 - Abstracts book. PO243: 228

BEDFORD I.D., BRIDDON R.W., BROWN J.K., ROSELL R.C., MARKHAM P.G., 1994 - Geminivirus transmission and biological characterisation of Bemisia tabaci (Gennadius) biotypes from different geographic regions. - Ann. Appl. Biol. 125: 311-325.

BOSCO D., DEMICHELIS S., SIMÒN B., RAPISARDA C., MORIONES E., CENIS J.L., 2001. Presence and distribution of Bemisia tabaci (Hemiptera: Aleyrodidae) biotypes in Italy, p. 29. In: European whitefly symposium, 27 February-3 March 2001, Ragusa, Sicily, Italy.

BOSELLI M., CAVAZZA F., FRANCESCHELLI F. 2018 Verifica dell'attività di sulfoxaflor (isoclast) nella lotta all'afide grigio del melo (Dysaphis plantaginea) - Atti Giornate Fitopatologiche 2018

BOTTACINI T., 2012 - Influenza di condizioni ambientali e modalita' di somministrazione sulla $\mathrm{DL}_{50}$ di insetticidi sistemici in Apis mellifera L. - Università degli Studi di Padova Corso di laurea in Scienze e Tecnologie Agrarie. 99pp.

BRAR G.S., MARTINI X., STELINSKI L.L., 2017 - Lethal and sublethal effects of a novel sulfoximine insecticide sulfoxaflor against Asian citrus psyllid and its primary parasitoid under laboratory and field conditions. - Int. J. Pest Manag. 63: 299-308.

BROWN JK., 2007 - The Bemisia tabaci complex: genetic and phenotypic variability drives Begomovirus spread and virus diversification. - APSnet Features, doi: 10.1094/APSnetFeature/20070107

BUZZETTI K., CHORBADJIAN R.A., NAUEN R., 2015 Resistance Management for San Jose Scale (Hemiptera: Diaspididae). - J. Econ. Entomol. 108: 2743-2752.

CAMPOS M.R., SILVA T.B.M., SILVA W.M., SILVA J.E., SIQUEIRA H.A.A., 2015 - Spinosyn resistance in the tomato borer Tuta absoluta (Meyrick) (Lepidoptera: Gelechiidae). - J. Pest. Sci. 88: 405-412.

CASIDA, J.E, 2018 - Neonicotinoids and other Insect Nicotinic Receptor Competitive Modulators: Progress and Prospects. Ann. Rev. Entomol. 63: 125-144

CENTNER T.J., BREWER B., LEAL I., 2018 - Reducing damages from sulfoxaflor use through mitigation measures to increase the protection of pollinator species. - Land Use Policy 75:70-76.

CHAILLEUX A., DROUI A., BEAREZ P., DESNEUX N., 2017 -
Survival of a specialist natural enemy experiencing resource competition with an omnivorous predator when sharing the invasive prey Tuta absoluta - Ecol. Evol. 7: 8329-8337.

CHEN X.D., STELINSKI L.L., 2017 - Rapid detection of insecticide resistance in Diaphorina citri (Hemiptera: Liviidae) populations, using a bottle bioassay. - Florida Entomol. 100: 124-133.

COCUZZA G.E.M., CONVERTINI S., BACCI L., RAPISARDA C., 2018a - Side effects of sulfoxaflor on Bombus terrestris (L.) (Hymenoptera, Apidae) in protected tomato crop. 14," meeting of the IOBC/WPRS Bulletin, Working Group "Integrated control in protected crops, Medterranean climate".

COCUZZA G.E.M., CONVERTINI S., BACCI L., RAPISARDA C., 2018b - Side effects of sulfoxaflor on Bombus terrestris (L.) (Hymenoptera, Apidae) in protected tomato crop - 14th meeting of the IOBC/WPRS Working Group "Integrated control in protected crops, Mediterranean climate" Oeiras (Lisbona) dal 4-7/9/2018.

CONVERTINI S., CIOFFI M., TESCARI E., FENIO A., BACCI L. 2018a - ISOCLAST ${ }^{\mathrm{TM}}$ : esperienze di controllo delle principali cocciniglie dei fruttiferi Atti Giornate Fitopatologiche 2018.

CONVERTINI S., CIOFFI M., TESCARI E., FENIO A., BACCI L. 2018b- ISOCLAST ${ }^{\mathrm{TM}}$ : Attività nei confronti di Aphis gossipii Glover su cucurbitaceae in pieno campo Atti Giornate Fitopatologiche 2018.

COSTA, L.M., GRELLA, T.C., BARBOSA, R.A., MALASPINA O., NOCELLI R.C.F., 2015 - Determination of acute lethal doses $\left(\mathrm{LD}_{50}\right.$ and $\left.\mathrm{LC}_{50}\right)$ of imidacloprid for the native bee Melipona scutellaris Latreille, 1811 (Hymenoptera: Apidae). Sociobiology 62: 578-582.

CUTLER P., SLATER R., EDMUNDS A.J.F., MAIENFISCH P., HALL R.G., EARLEY F.G.P., PITTERNA T., SITARAM P., PAUL V.L., GOODCHILD J., BLACKER M., HAGMANN L., CROSSTHWAITE A.J. 2013 - Investigating the mode of action of sulfoxaflor: a fourth-generation neonicotinoid - Pest Manag. Sci. 69: 607-619.

DE BARRO P.J., LIU S.S., BOYKIN L.M., DINSDALE A.B., 2011 - Bemisia tabaci: a statement of species status. - Ann. Rev. Entomol. 56: 1-19.

DEMICHELIS S., BOSCO D., MANINO A., 2000 - Distribution of Bemisia tabaci (Hemiptera: Aleyrodidae) biotypes in Italy Canad. Entomol. 132: 1-9.

DESNEUX N., DECOURTYE A., DELPUECH J.M., 2007 - The sublethal effects of pesticides on beneficial arthropods. - Ann. Rev. Entomol. 52: 81-106.

DINSDALE A., COOK L., RIGINOS C., BUCKLEY Y.M., DE BARRO P.J., 2010 - Refined global analysis of Bemisia tabaci (Hemiptera: Sternorrhyncha: Aleyrodoidea: Aleyrodidae) mitochondrial cytochrome oxidase 1 to identify species level genetic boundaries. - Ann. Entomol. Soc. Am. 103: 196-208.

DOW AGROSCIENCES, 2017- Technical Bulletin 75 pp

ELBAZ M., WEISER M., MORIN S., 2011 - Asymmetry in thermal tolerance trade-offs between the 8 and Q sibling species of Bemisia tabaci (Hemiptera: Aleyrodidae). - J. Evol. Biol. 24: 1099-1109.

FANG, Y., JIAO X., XIE W., WANG S., WU Q., SHI X., CHEN G., SU Q. , YANG X. , PAN H., ZHANG Y. , 2013 Tomato yellow leaf curl virus alters the host preferences of its vector Bemisia tabaci. Sci. Rep. 3, 2876.

GARZON A., MEDINA P., AMOR F., VINUELA E., BUDIA F., 2015 - Toxicity and sublethal effects of six insecticides to last instar larvae and adults of the biocontrol agents Chrysoperla carnea (Stephens) (Neuroptera: Chrysopidae) and Adalia bipunctata (L.) (Coleoptera: Coccinellidae) - Chemosphere 132: 87-93. 
GORE J., COOK D., CATCHOT A., LEONARD BR., STEWART SD., LORENZ G., KERNS D. 2013 - Cotton Aphid (Heteroptera: Aphididae) Susceptibility to Commercial and Experimental Insecticides in the Southern United States - J. Econ. Entomol. 106: 1430-1439.

GUEDES R.N.C., SMAGGHE G., STARK L.D., DESNEUX N., 2016 - Pesticide-Induced Stress in Arthropod Pests for Optimized Integrated Pest Management Programs. - Ann. Rev. Entomol. 61: 43-62.

HOROWITZ, A. R., KONTSEDALOV, S., KHASDAN, V., ISHAAYA, I. 2005 Biotypes B and Q of Bemisia tabaci and their relevance to neonicotinoid and pyriproxyfen resistance. Arch. Insect. Biochem. 58: 216-225.

HSIEH C.H., WANG H.Y., CHEN Y.F., KO C.C., 2012 - Loop-mediated isothermal amplification for rapid identification of biotypes B and Q of the globally invasive pest Bemisia tabaci, and studying population dynamics. Pest. Manag. Sci. 68: 1206-1213.

IIDA H., KITAMURA T., HONDA K. 2009 - Comparison of egghatching rate, survival rate and development time of the immature stage between 8-and Q-biotypes of Bemisia tabaci (Gennadius) (Homoptera: Aleyrodidae) on various agricultural crops. - Appl. Entomol. Zool. 44: 267-273.

IWASA T.; MOTOYAMA N.; AMBROSE J.T., ROE RM., 2004 - Mechanism for the differential toxicity of neonicotinoid insecticides in the honey bee, Apis mellifera - Crop Protect. 23: 371-378.

KONTSEDALOV S., BU-MOCH F., LEBEDEV G., CZOSNEK H., HOROWITZ A.R., GHANIM M., 2012 - Bemisia tabaci Biotype Dynamics and Resistance to Insecticides in Israel During the Years 2008-2010. - J. Integ. Agr. 11: 312-320.

LAURINO D., MANINO A., PATETTA A., ANSALDI M., PORPORATO M., 2010 - Acute oral toxicity of neonicotinoids on different bee strains. - Redia, 93: 99-102.

LAURINO D., MANINO A., PATETTA A., PORPORATO M. 2013 -Toxicity of neonicotinoid insecticides on different honey bee genotypes - Bull. Insectol. 66: 119-126

LAWRENCE I.G., SARJEET S.G., 2010 - Insect Control: Biological and Synthetic Agents. - Elsevier, London UK: 490 pp.

LEBARON M.J., GETER D.R., RASOULPOUR R.J., GOLLAPUDI B.B., THOMAS J., MURRAY J., KAN H.L., WOOD A.J., ELCOMBE C., VARDY A., MCEWAN J., TERRY C., BILLINGTON R.AF., 2013 - An integrated approach for prospectively investigating a mode-of-action for rodent liver effects - Toxicol. Appl. Pharmacol. 270: 164-173

LIANG P., TIAN Y.A., BIONDI A., DESNEUX N., GAN X.W., 2012 - Short-term and transgenerational effects of the neonicotinoid nitenpyram on susceptibility to insecticides in two whitefly species. - Ecotoxicology 21: 1889-1898.

LIAO X., MAO K.K., ALI E., ZHANG X.L., WAN H., LI J.H., 2017 - Temporal variability and resistance correlation of sulfoxaflor susceptibility among. Chinese populations of the brown planthopper Niloparvata lugens (Stal). Crop Protect. 102: 141-146.

LIU B., YAN F., CHU D., PAN H., JIAO X., XIE W., WU Q., WANG S., XU B., ZHOU X., ZHANG Y., 2012 - Difference in Feeding Behaviours of Two Invasive Whiteflies on Host Plants with Different Suitability: Implication for Competitive Displacement. - Int. Biol. Sci. 8: 697-706.

LONGHURST C., BABCOCK J.M., DENHOLM I., GORMAN K., THOMAS J.D., SPARKS T.C., 2013 -. Cross-resistance relationships of the sulfoximine insecticide sulfoxaflor with neonicotinoids and other insecticides in the whiteflies Bemisia tabaci and Trialeurodes vaporariorum - Pest Manag. Sci. Back. 69: 809-813.
LUO C., JONES C.M., DEVINE G., ZHANG F., DENHOLM I., GORMAN K., 2010 - Insecticide resistance in Bemisia tabaci biotype Q (Hemiptera: Aleyrodidae) from China. - Crop. Prot. 29: 429-434.

MAHADAV A., KONTSEDALOV S., CZOSNEK H., GHANIM M., 2009 - Thermotolerance and gene expression following heat stress in the whitefly Bemisia tabaci B and Q biotypes. Insect. Biochem. Molec. 39: 668-676.

NAVAS-CASTILLO J., FIALLO-OLIVÉ E., SÁNCHEZ CAMPOS S., 2011 - Emerging virus disease transmitted by whiteflies. - Ann. Rev. Phytopathol. 49: 219-248.

OLIVEIRA E.E,, SCHLEICHERA S., BÜSCHGES A.,, SCHMIDT J., KLOPPENBURG P., SALGADO V.L., 2011 Desensitization of nicotinic acetylcholine receptors in central nervous system neurons of the stick insect (Carausius morosus) by imidacloprid and sulfoximine insecticides. Insect Biochem. Mol. Biol. 41: 872-880.

RODITAKIS E., VASAKIS E., GRISPOU M., STAVRAKAKI M., NAUEN R., GRAVOUIL M., BASSI A., 2015 - First report of Tuta absoluta resistance to diamide insecticides. - J. Pest Sci. 88: 9-16.

ROUSH R.T., TABASHNIK B.E. (eds.), 1991 - Pesticide Resistance in Arthropods. - Springer, US: 303 pp.

SERDAR S., ARSLAN A., CHLORIDIS A., 2018 - Evaluation of the insecticide sulfoxaflor on important beneficial arthropods in citrus ecosystems in Turkey. - Integrated Control in Citrus Fruit Crops IOBC-WPRS Bulletin 132: 132-140.

SIVITER H., BROWN M. J. F., LEADBEATER E., 2018 Sulfoxaflor exposure reduces bumblebee reproductive success. Nature 561: 109

SMITH HA., GIURCANU MC., 2013 - Residual effects of new insecticides on egg and nymph densities of Bemisia tabaci (Hemiptera: Aleyrodidae). - Florida Entomol. 96: 504-511.

SPARKS T.C., DEBOER G.J., WANG N.X., HASLER J.M., LOSO M.R., GERALD B. WATSON G.B. 2012 - Differential metabolism of sulfoximine and neonicotinoid insecticides by Drosophila melanogaster monooxygenase CYP6G1 Pesticide Biochem. Physiol. 103: 159-165.

TANG QL., XIANG M., HU H.M., AN C.J., GAO X.W., 2015 Evaluation of Sublethal Effects of Sulfoxaflor on the Green Peach Aphid (Hemiptera: Aphididae) using Life Table parameters. - J. Econ. Entomol. 108: 2720-2728.

TESCARI E., FENIO A., BACCI L., BRADASCIO R., GIBERTI A., 2016 - Sulfoxaflor (Isoclast ${ }^{\mathrm{TM}}$ Active, Closer ${ }^{\mathrm{TM}}$ ), nuovo insetticida di Dow Agrosciences. Caratteristiche generali e risultati sperimentali. - Atti Giornate Fitopatologiche, 1: $3-12$

TOMIZAWA M., CASIDA J.E., 2003 - Selective toxicity of neonicotinoids attributable to specificity of insect and mammalian nicotinic receptors - Ann. Rev. Entomol. 48:339-364

VANEGAS M., 2017 - The Silent Beehive: How the Decline of Honey Bee Populations Shifted the Environmental Protection Agency's Pesticide Policy towards Pollinators. - Ecol. Law Quart. 44: 311-341.

WANG Z., YAN H., YANG Y., WU Y., 2010 - Biotype and insecticide resistance status of the whitefly Bemisia tabaci from China. - Pest. Manag. Sci. 66: 1360-1366.

WATSON G.B., LOSO M.R., BABCOCK J.M., HASLER J.M., LETHERER T.J., YOUNG C.D., ZHU Y., CASIDA J.E., SPARKS T.C., 2011 - Novel nicotinic action of the sulfoximine insecticide sulfoxaflor. - Insect Biochem. Mol. Bio. 41: 432-439.

WEI X., PAN Y., XIN X., ZHENG C., GAO X., XI J., SHANG Q., 2017 - Cross-resistance pattern and basis of resistance in a thi- 
amethoxam-resistant strain of Aphis gossypii Glover. Pesticide Biochem. Physiol. 138: 91-96.

WISLER G.C., DUFFUS E., LIU H.Y., LI R.H., 1998 - Ecology and epidemiology of whitefly-transmitted closteroviruses.Plant Dis. 82: 270-280.

XU L., ZHAO C.Q., XU D.J., XU G.C., XU X.L., HAN Z.J., ZHANG Y.N., GU Z.Y, 2017 - RNAi suppression of nuclear receptor genes results in increased susceptibility to sulfoxaflor in brown planthopper, Nilaparvata lugens. - J. Asia-Pacific Entomol. 20: 645-653.

ZASADA I., HÄFNER K., SCHALLER L., VAN ZANTEN B.T., LEFEBVRE M., MALAK-RAWLIKOWSK A., NIKOLOV D., RODRÍGUEZ-ENTRENA M., MANRIQUE R., UNGARO F., ZAVALLONI M., DELATTRE L., PIORR A., KANTELHARDT J., VERBURG P.H., VIAGGI D. 2017 - A conceptual model to integrate the regional context in landscape policy, management and contribution to rural development: Literature review and European case study evidence. Geoforum 82: 1-12.

ZHU Y.C., YAO J.X., ADAMCZYK J., LUTTRELL R., 2017 Feeding toxicity and impact of imidacloprid formulation and mixtures with six representative pesticides at residue concentrations on honey bee physiology (Apis mellifera) - Plos One 7:1-19.

ZHU Y.M., LOSO M.R., WATSON G.B., SPARKS T.C., ROGERS R.B., HUANG J.X., GERWICK B.C., BABCOCK J.M., KELLEY D., HEGDE V.B., NUGENT B.M., RENGA J.M., DENHOLM I., GORMAN K., DEBOER G.J., HASLER J., MEADE T., THOMAS J.D., 2011 - Discovery and Characterization of Sulfoxaflor, a Novel Insecticide Targeting Sap-Feeding Pests. - J. Agricult. Food Chem. 59: 2950-2957. 